\title{
Evaluation of Social Studies Teachers' Usage Situation of Literary Works in Their Courses: Bartın Sample
}

\author{
Harun ER*a, Selahattin KAYMAKCI
}

\begin{tabular}{l} 
Article Info \\
\hline DOI: $10.14686 /$ buefad.457915 \\
\hline Article History: \\
Received 06.04.2018 \\
Accepted $\quad 01.10 .2018$ \\
Published $\quad 31.10 .2018$ \\
\hline Keywords: \\
Social studies \\
Literary work \\
Teacher \\
\hline Article Type: \\
Research Article \\
\end{tabular}

\begin{abstract}
Literature can be defined as a branch of art by which people express their emotions, thoughts, imaginations and ideals verbally or in written through language. It is one of the many fields utilized by social studies courses that inherently involve several social disciplines. Several different type of literary works have been used as teaching materials in social studies teaching. These primarily involve novels, stories, memoirs, biographies, travel writings, sagas, epics, articles, proverbs, songs, idioms, legends, poems, tales and theater plays. The aim of this study is to determine the extent to which social studies teachers use literary works in their courses. Phenomenology among qualitative methodologies was used during the research. The study group consists of 32 social studies teachers working in Bartın province as of 2015-2016 academic year. Structured interview was used as the data gathering tool. The data obtained within the frame of the study were analyzed using content analysis. As a result of the research, the majority of participating teachers were found to be inclined to use literary works in their courses, although they find the use of literary works in curricula and course books qualitatively and quantitatively inadequate.
\end{abstract}

\section{Sosyal Bilgiler Öğretmenlerinin Derslerinde Edebi Ürün Kullanma Durumlarının Değerlendirilmesi: Bartın Örneği}

\begin{tabular}{|c|c|}
\hline \multicolumn{2}{|c|}{ Makale Bilgisi } \\
\hline DOI: 1 & 86/buefad.457915 \\
\hline $\begin{array}{l}\text { Makal } \\
\text { Geliş } \\
\text { Kabul } \\
\text { Yayın }\end{array}$ & $\begin{array}{l}\text { mişi: } \\
06.04 .2018 \\
01.10 .2018 \\
31.10 .2018\end{array}$ \\
\hline $\begin{array}{l}\text { Anahtc } \\
\text { Sosyal } \\
\text { Edebi } \\
\text { Öğretn }\end{array}$ & $\begin{array}{l}\text { imeler: } \\
\text { ler }\end{array}$ \\
\hline $\begin{array}{l}\text { Makal } \\
\text { Araştır }\end{array}$ & $\begin{array}{l}\ddot{u}: \\
\text { Takalesi }\end{array}$ \\
\hline
\end{tabular}

\begin{abstract}
$\ddot{\mathbf{O}} \mathbf{z}$
Edebiyat insanların duygu, düşünce, hayal ve ideallerini dil vasıtasıyla sözlü ve yazılı bir biçimde ifade ettikleri bir sanat olarak tanımlanabilir. Doğası itibariyle sosyal bilim dallarını içinde barındıran sosyal bilgiler dersinin yararlandığı yakın çalışma alanlarından birisi de edebiyattır. Sosyal bilgiler öğretiminde edebiyata ilişkin farklı türde birçok edebi ürün bir ders aracı olarak kullanılmaktadır. Bunlar arasında başlıcaları; roman, hikâye, anı, biyografi, gezi yazısı, destan, menkıbe, makale, atasözü, şark1, deyim, efsane, mani, masal ve tiyatro sayılabilir. $\mathrm{Bu}$ araştırmanın amacı sosyal bilgiler ögretmenlerinin derslerinde edebi ürün kullanma durumlarını ortaya koymaktır. Araştırmada nitel metodoloji kapsamında olgubilimden yararlanılmıştır. Araştırmanın çalışma grubunu, 2015-2016 eğitimögretim yılı bahar yarıyılında Bartın ilinde görev yapan toplam 32 sosyal bilgiler öğretmeni oluşturmaktadır. Araştırmada veri toplama aracı olarak yapılandırılmış mülakattan yararlanılmıştır. Araştırma kapsamında toplanan veriler içerik analizi yardımıyla çözümlenmiştir. Araştırma sonucunda, sosyal bilgiler öğretmenlerinin çoğunluğunun derslerinde edebi ürün kullanmaya istekli oldukları ancak ögretim programı ve ders kitaplarında edebi ürün kullanımını nitelik ve nicelik açısından yetersiz gördükleri ortaya çıkmıştır.
\end{abstract}

\footnotetext{
*Corresponding Author: erharun06@gmail.com

a Asst. Prof. Dr., Bartin University, Faculty of Education, Bartin/TURKEY, https://orcid.org/0000-0002-0454-6807

b Assoc. Prof. Dr., Kastamonu University, Faculty of Education, Kastamonu/TURKEY, https://orcid.org/0000-0001-59059902
} 


\section{Introduction}

As a fundamental requirement for human life, education defines a period that covers a specific time span in an individual's life. Throughout this period, individuals' ability to fulfil their vital needs and establish communication with others through expressing themselves, i.e. their ability to socialize holds great importance. Human beings are inherently social creatures and they feel the need to fulfil their social requirements through living in a society. Fulfillment of these social requirements within the educational period is the primary subject of social studies courses among the related fields of study.

Social studies courses investigate individuals' interaction with their social and physical environment within the context of past, present and future on the basis of a collective education approach (MEB, 2005a). In this sense, the general aim of social studies course is to educate individuals with effective communicational skills that effectively contribute to their society through adoption of social knowledge, skills and values and that love their country (Doğanay, 2005; Yeşilbursa and Sabanc1, 2015).

Social studies course has an interdisciplinary structure that incorporates interrelated knowledge, skills and values, thus providing an organized teaching (MEB, 2018). Both the intertwined structure of social phenomena and the indiscernibility of social problems in political, social and economic terms require utilization of diverse disciplines in the field of social studies (Kaymakc1, 2010). In this regard, establishment of teaching environments that help students get connected with real life and have sound life experiences is required throughout the education period, which in turn necessitates the use of diverse strategies, methods, techniques and teaching aids and materials (Meydan and Akdağ, 2014; Yıldırım, 2017). Also, course contents can be associated with similar fields such as culture, art, media and literature (Akdağ, 2009). Among these fields, literature holds particular importance, as it features similar properties with the field of social studies. They both put their primary emphasis on humans, involve an intense reading, writing and speaking process, and inherently undertake the role of a culture communicator, which are indicative of the intrinsic bond between these two fields (Akkuş, 2006; Ünlü, 2016).

The relationship between social studies and literature manifests itself in curricula as well. Two articles in the "explanations about the implementation of program" section of the social studies curriculum, that took effect as of year 2005, include recommendations regarding the use of literary works in social studies courses. In this regard, social studies teachers are prompted to utilize literary works and written materials (legends, sagas, tales, proverbs, folktales, ballads and poems, etc.), and social studies should blend literature and geography, as a means for equipping students with the love of their country and nation. Moreover, social studies teachers should motivate their students to read novels, historical novels, stories, memoirs, travel writings, poems and anecdotes to draw the interest of their students to course subjects (MEB, 2005a: 6-8; MEB, 2005b: 7-10). A similar approach was adopted in the social studies curriculum that took effect as of 2017-2018 academic year. In this frame, teachers were reminded to use literary works such as legends, sagas, tales, proverbs, folktales, ballads and poems, to draw their students' interest (MEB, 2018: 10).

Students are provided with several opportunities to acquire fundamental skills through the use of literary works in social studies courses. In these courses, development of reading, writing, speaking and listening skills is primarily promoted, thus, students learn how express themselves, establish communication and empathy, acquire diverse perspectives and respect human personality. Literary works also contribute to the development of sensitivity, raising a cultural awareness, and acquisition of a democratic culture texture. The understanding, comprehending, thinking and criticizing skills of students can be developed to help them regard their lives in a more positive manner and acquire a social personality. Also, students' creativity can be developed through exalting their spirits by the help of art, by equipping them with aesthetical feelings of an artist (Kuran and Ersözlü, 2009; Öztürk and Otluoğlu, 2002; Sever, 1998).

Literary works enable materialization of intangible contents, which arouse students' interest. They enable cultural communication through teaching students national and universal values. Literature works allow students have a good time through exemplification of real life experiences (Akkuş, 2007; Chapin and Messick, 1999; Çencen, 2010; Garcia and Michaelis, 2001; Köksal, 2010; Tekgöz, 2005; Turk et al., 2007; Oğuzkan, 2001; Öztürk and Otluoğlu, 2010; Top, 2009; ref. Kaymakc1, 2013). This way, students' critical thinking capabilities are enhanced which facilitate interpretation of current events, and establishing a link between the present and the past through comparison of events (Altun and Ata, 2008; Çengelci, 2013; Dönmez and Altıkulaç 2014). Literary works establish a link between the concepts of "past, present and future", and "change, development and 
continuity", thus enabling students to explore/analyze the relationship between these concepts (Kaya and Ekiçi, 2015; Krey, 1998). They also contribute to the process of taking reputed people as role models, thus acquisition of specific values possessed and practiced by these people (Er and Şahin, 2012).

Various studies have been performed on the use of literary works, which have such a close relationship with social studies teaching, in the field of social studies and course contents. The findings of these researches indicate that, the use of literary works results in increased academic success (Akkuş, 2007; Altunay-Şam, 2011; Altunay-Şam and İskender-Kılıç, 2011; Arslan, 2014; Bacak, 2008; Bölücek, 2008; Çifçi, 2011; Erdem, 2010; Gevenç, 2014; Keskin, 2008; Öztürk, 2002; Şimşek, 2000; Tekgöz, 2005; Top, 2009; Yeşilbursa and Sabanc1, 2015; Yiğit, 2007), develops historical thinking skills and creativity (Bacak, 2008; Erdoğan, 2007), contributes to the development of the tendency to empathize, (Akyol, 2011), and develops a positive attitude towards the course (Demir, 2011; Oruç and Erdem, 2010; Öztürk and Otluoğlu, 2002; Top, 2009). The place of literary works in the related courses' textbooks have been adressed as well (Kaymakc1, 2012; Kaymakc1, 2013; Kaymakcı and Er, 2013; Oruç, 2009; Yeşilbursa, Sabancı and Hamarat, 2013). The opinions of students (Çencen, 2017; Er, 2008; Er, 2010; Er and Şahin, 2012; Kaymakc1, 2008; Şimşek, 2006a; Şimşek, 2006b), teacher candidates (Beldağ and Aktaş, 2016; Dönmez and Altıkulaç, 2014; Tokdemir, 2016; Ünlü and Kaşkaya, 2018; Yeşilbursa and Sabanc1, 2015) and teachers (Beldağ and Aktaş, 2016; Çencen and Akça-Berk, 2014; İbret, Karasu-Avc1, Karabıyık, Güleş and Demirci, 2017; Mertol, 2008; Şimşek, 2006a; Topçu and Kaymakc1, 2018; Ünlü, 2016; Yıldırım, 2017) were also asked in these studies.

Beldağ and Aktaş (2016) addressed the relationship between social studies and literary works and evaluated teachers' and teacher candidates' opinions regarding the use of literary works in social studies courses. The research was carried out with 48 participants ( 24 social studies teachers and 24 social studies teacher candidates) and the type of literary works that are/could be used in social studies teaching, the properties expected from them, the potential teaching fields in which literary works can be used, and titles of literary works were focused.

Çencen and Akça-Berk (2014) evaluated teacher opinions on the use of poems as literary works. In this context, teachers' opinions on the use of poems in their courses were evaluated on the basis of some of the variables (gender, the type of school in which they work, their professional seniority and their final graduation).

İbret, Karasu-Avcı, Karabıyık, Güleş and Demirci (2017) investigated the extent to which students use literary works in values education. In this frame, the importance of the use of literary works in values education, the extent to which literary works are used in values education, literary works used in values education, and the contributions of the use of literary works to courses in values education were addressed.

Mertol (2008), investigated the extent to which teachers used childrens' literature works in their courses. In this regard, the differences in teacher opinions were evaluated based on specific variables (gender, real branch, and professional seniority), and the children's novel read by teachers in their childhood were determined.

Şimşek (2006a) evaluated the student (223 participants) and teacher (30 participants) opinions as to the use of historical novels in social studies courses. In this frame, student opinions on historical novels were comparatively evaluated on the basis of their school, gender, grade level and their historical-movie-watchingstatus; and teacher opinions on historical novels were evaluated on the basis of their gender, graduation, seniority, reading-status and periodical-publication-following-status.

Topçu and Kaymakcı (2018) investigated whether teachers used sagas in their courses. They accordingly evaluated teacher opinions on the definition and educational benefits of sagas, the place of sagas in social studies curricula and textbooks, as well as the adequacy levels for the use of sagas in social studies courses.

Ünlü (2016) investigated teacher opinions on the use of literary works as teaching materials. The study was carried out with 20 participants from Erzincan province and it focused on the issues such as the types of literary works preferred by teachers, the criteria used for selection of literary works, and the course subjects and stages for which teachers utilized literary works.

Yildırım (2017) carried out a study to reveal the extent to which teachers used literary works and whether they encounter related problems. The research was performed with participation of 20 teachers in Erzurum province, and the subjects such as teachers' literary-works-usage-levels, their purposes for using literary works, the criteria they used for choosing between literary works, the types of literary works they use, how they provide 
them, how they use literary works in their courses and the problems they encounter when they use literary works in their courses, were addressed.

A collective evaluation of these studies in the field reveal that, the studies partially focus on the general use of literary works (Beldağ and Aktaş, 2016; Ünlü, 2016; Yıldırım, 2017), while others focus on the use of children's literature works (Mertol, 2008), literary genres (Çencen and Akça-Berk, 2014; Şimşek, 2006a; Topçu and Kaymakc1, 2018) and the relationship between values education and the use of literary works (İbret, KarasuAvcı, Karabıyık, Güleş and Demirci, 2017). On the other hand, the studies on the general use of literary works were conducted in Rize (Beldağ and Aktaş, 2016), Erzincan (Ünlü, 2016) and Erzurum (Yıldırım, 2017). These studies however adopted a qualitative methodology which indicates that the opinions evaluated are limited to those of the people from these areas, and this brings about the necessity to perform studies in other regions as well. The present research was accordingly performed with a view to give variety to the studies in the field, and to reveal the requirements for further studies.

\section{Aim}

This research aims to reveal the extent to which social studies teachers use literary works in their courses. Answers to the following questions were sought in the research:

1. Which literary works do teachers enjoy to follow in their daily lives?

2. What are teachers' opinions on the place of literary works in social studies curriculum and related textbooks?

3. On what grounds do teachers use literary works in their courses?

4. Which literary genres do teachers use in their courses?

5. Which problems do teachers encounter related to the use of literary works in social studies courses?

6. What do teachers recommend as to the effective use of literary works in social studies courses?

\section{Method}

The research was designed by a qualitative approach, by definition. As known, qualitative research deals with the perspectives and semantic worlds of study subjects and attempts to put forth an in situ, realistic and integrated account of the events and situations through their eyes (Yıldırım and Şimşek, 2011; Kuş, 2012). In the research, phenomenology, among qualitative methodologies, was adopted to gain insight into the past experiences of teachers, to learn how they perceive and interpret the research's subject (Patton, 2014), and due to its suitability to the aim of the research.

\section{Study Group}

The study group consists of 32 social studies teachers working in Bartın province as of the spring term of 2015-2016 academic year. Convenience sampling method among purposive sampling methods was preferred while choosing the study group. This sampling technique was preferred as it provides conveniences related to time, cost, effort, and accessibility (Patton, 2014).

The required approvals were received before determining the study group. Afterwards, the schools in the regions were visited and social studies teachers were informed about the aim of the research, data collection tools, and the analysis methods used. The research was carried out with the teachers who consented to participate in the research. The demographic information of participating teachers are as follows:

Table 1. Information related to the gender of teachers

\begin{tabular}{|c|c|c|}
\hline Gender & $\mathbf{n}$ & $\%$ \\
\hline Female & 14 & 43.75 \\
\hline Male & 18 & 56.25 \\
\hline Total & 32 & 100 \\
\hline
\end{tabular}

Gender information of participating teachers is given in Table 1. As shown in the table, $43.75 \%$ of the participants are female and $56.25 \%$ of the participants are male. It can be accordingly inferred that, participants exhibit a nearly homogeneous distribution in terms of gender. 
Table 2. Information related to the professional experiences of teachers

\begin{tabular}{lcc}
\hline \multicolumn{1}{c}{ Professional experience } & n & \% \\
\hline 1-5 years & 5 & 15.63 \\
6-10 years & 6 & 18.75 \\
11-15 years & 8 & 25.00 \\
16-20 years & 9 & 28.12 \\
20 years and more $\quad$ Total & 4 & 12.50 \\
\hline \multicolumn{1}{c}{$\quad$ 32 } & $\mathbf{1 0 0}$ \\
\hline
\end{tabular}

Information related to the professional experiences of teachers are shown in Table 2. Accordingly, $15.63 \%$ of the participants have $1-5$ years, $18.75 \%$ have $6-10$ years, $25 \%$ have $11-15$ years, $28.12 \%$ have $16-20$ years and $12.50 \%$ have 20 years and higher professional experience. Accordingly, the majority of teachers can be considered to have a good professional experience.

Table 3. Graduation information of teachers

\begin{tabular}{|c|c|c|}
\hline Program Type & $\mathbf{n}$ & $\%$ \\
\hline Social Studies Teaching & 13 & 40.63 \\
\hline History Teaching & 9 & 28.12 \\
\hline Geography Teaching & 6 & 18.75 \\
\hline Other & 4 & 12.50 \\
\hline Total & 32 & 100 \\
\hline
\end{tabular}

Information as to the graduation of teachers are given in Table 3. As indicated in the table, 40.63 of the participating teachers graduated from social studies, $28.12 \%$ graduated from history teaching, $18.75 \%$ graduated from geography teaching and the remaining $12.50 \%$ graduated from other fields (classroom teaching, etc.). It can be inferred that, the majority of the participants consist of faculty of education, department of social studies teaching graduates.

\section{Data Collection Tool and its Development}

Structured interview was used as the data collection tool. This technique was preferred as it allows determination of similarities and differences among participant responses, and making comparisons between them (Yıldırım ve Şimşek, 2011).

An in-depth literature survey was performed during the development stage of the data collection tool. In the next stage, a draft interview form was prepared. The draft form consisted of two parts. The first part included questions related to the demographic properties of participants. The second part involved questions as to the literary works that the participants enjoyed following in their daily lives, the types of literary works they use in their social studies courses, situations they encounter while using literary works, how the literary works they used contributed to their teaching, and their opinions as to how literary works can be used more efficiently in social studies courses. The prepared interview form was examined by two academicians in the field of social studies, a teacher who graduated from the social studies teaching program, and a Turkish Language teacher for linguistic check. Afterwards, a pre-application process was performed with three non-participating social studies teachers and the form was finalized in accordance with the resulting opinions.

\section{Data Collection}

Research data were collected in 01 January-1 March 2016 period from the social studies teachers working in Bartın province who consented to participate in the research. Data collection process was performed via face-toface interviews, through noting down the teacher opinions.

\section{Data Analysis}

The research data obtained in the study were analyzed using content analysis. This method was preferred as it allows determination of individuals' interests, and the presence of specific words, concepts and their relationship within the obtained data, in addition to digitalization of data during analysis (Büyüköztürk, Kılıç-Çakmak, Akgün, Karadeniz and Demirel, 2008). 
During the data analysis stage of the research, initially coding was performed, then the categories and the themes were determined and finally they were tabulated as frequency and percentage. For verification of the data analysis, direct teacher opinions were directly used so as to represent the themes. For ensuring the reliability of the data analysis, investigator triangulation (Patton, 2014) was performed. The research data were separately analyzed by the researchers. The performed analyses were estimated by the Miles and Huberman's (1994) reliability formula, and the percentage of agreement was found as $84.73 \%$. In this context, the data upon which the researchers agreed were demonstrated in the findings, and non-agreeing data were excluded from the classification. Also, confidentiality dimension was taken into account during the data analysis, and accordingly pseudonyms (K-1, K-2 etc.) were used instead of the real names of the participating teachers.

\section{Results and Discussion}

The following results were obtained in this research that aimed to determine the extent to which social studies teachers use literary works in their courses:

\section{- The types of literary works that teachers enjoy following in their daily lives:}

The responses of social studies teachers as to the types of literary works they like to follow in their daily lives are shown in Table 4.

Table 4. The types of literary works that social studies teachers like to follow in their daily lives

\begin{tabular}{lcc}
\hline \multicolumn{1}{c}{ Opinions } & f & \% \\
\hline Novels, stories, poems, theaters and songs/ballads & 14 & 45.16 \\
\hline Articles, socio-political writings and up-to-date journals & 8 & 25.80 \\
\hline Historical artifacts, sagas, biographies and memoirs & 7 & 22,58 \\
\hline Geographical journals and travel writings & 2 & 6,45 \\
\hline
\end{tabular}

The types of literary works that social studies teachers like to follow in their daily lives are shown in Table 4. As indicated in the table, the types of literary works are listed as; novels, stories, poems, theaters and songs/ballads (14), articles, socio-political writings, and up-to-date journals (8), historical artifacts, sagas, biographies and memoirs (7), and geographical journals and travel writings (2) in the descending order of participants' preferences. The literary works that social studies teachers generally like to follow in their daily lives seem to involve the genres such as novel, story and poem that constitute the classical basis for literary works. This situation indicates that, these literary works still maintain their influence within their own context, and that teachers have a tendency towards regular reading. The participants' tendency to prefer visual and auditory genres such as theater and song/ballad, which have the potential to emotionally influence humans, can be ascribed to the fact that, teachers regard these as a need in their lives. Other literary works' being less favored with similar percentages is indicative of their being adopted in a general sense, although without a sustainable interest of teachers.

Social studies teachers' opinions related to the literary genres they like to follow in their daily lives are as follows; K5: "I rather like to read novels, stories, articles and various research articles", K13: "I particularly like to read historical novels, biographies and poem books in my leisure times”, K11: "Up-to-date journals and periodicals are among the literary writings that i like to follow".

\section{- Opinions of teachers regarding the place of literary works in social studies curriculum and textbooks:}

The negative and positive opinions of social studies teachers regarding the place of literary works in social studies curriculum and textbooks are shown in Tables 5 and 6. 
Table 5. Opinions of social studies teachers regarding the adequacy of literary works in social studies curriculum and textbooks

\begin{tabular}{|c|c|c|}
\hline Opinions & $\mathbf{f}$ & $\%$ \\
\hline Adequate & 5 & 38.46 \\
\hline Adequate, but the course period is not adequate & 5 & 38.46 \\
\hline Adequate, but the samples related to the subject are inadequate & 3 & 23,07 \\
\hline & 13 & 100 \\
\hline
\end{tabular}

The positive opinions of social studies teachers related to the adequacy of literary works in social studies curriculum and textbooks are given in Table 5. As shown in the table, the most preferred opinions are; adequate (5), adequate but the course period is not adequate (5), adequate but the samples related to the subject are not adequate (3), respectively. The general positive opinions of social studies teachers regarding the adequacy of literary works in social studies curriculum and textbooks show that, they find the course periods and the use of related samples inadequate while they find the use of literary works adequate, which is indicative of their sensitivity regarding the subject. This holds particular importance for effective utilization of literary works in the course, and provision of students with an effective learning period.

Some of the positive opinions of social studies teachers regarding the use of literary works in social studies curriculum and textbooks are: K12: "I can state that it is adequate, but $i$ think the course lacks diversity of samples", K3: "Although i find it adequate, the course period obviously falls short for this purpose. Therefore, we fail to bring several literary works to the course environment".

Table 6. Negative opinions of social studies teachers regarding the adequacy of literary works in the social studies curriculum and textbooks

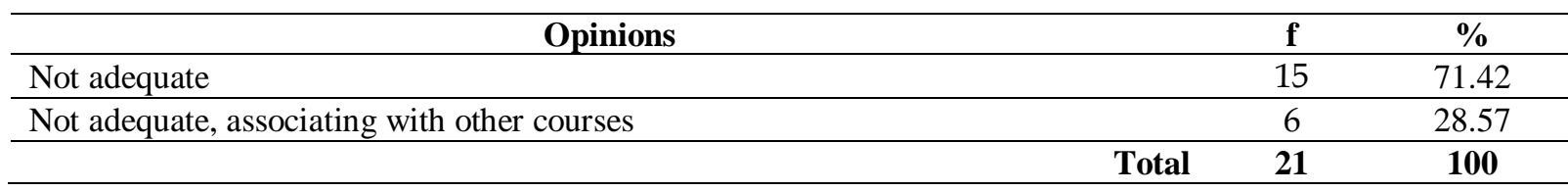

The negative opinions of social studies teachers related to the adequacy of literary works in social studies curriculum and textbooks are given in Table 6. As shown in the table, the most preferred opinions are; not adequate (15), and associating with other courses (6), respectively. The general negative opinions of social studies teachers as to the adequacy of literary works in social studies curriculum and textbooks show that, they mostly find it inadequate and they think that it is not reflected upon the courses in real terms. This is indicative of the positive attitude of teachers towards the use of literary works in social studies courses. Particularly, their being inclined to associate this with other courses supports this notion.

The negative opinions of social studies teachers regarding the use of literary works in social studies curriculum and textbooks are; K22: "I think literary works are not sufficiently included, we use our own sources", K8: "I find it inadequate, but we address it by associating with Turkish Language lesson".

\section{- Rationale for the use of literary works by teachers:}

The answers of social studies teachers regarding their rationale for using literary works in social studies courses are given in Table 7.

Table 7. Rationale of social studies teachers for using literary works in their courses

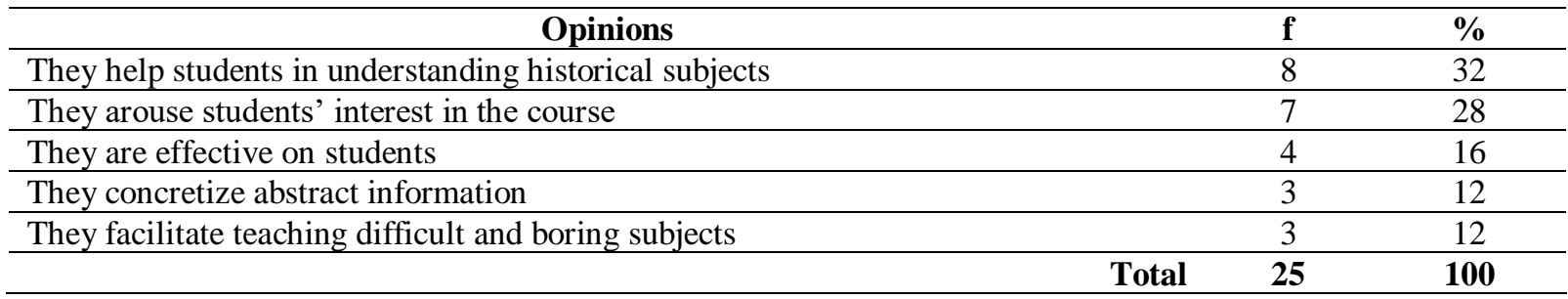


Table 7 shows the opinions of social studies teachers regarding the use of literary works in their courses. As shown in the table, the most preferred opinions are; "they help students in understanding historical subjects" (8), they arouse students' interest in the course (7), "they are effective on students" (4), "they concretize abstract information" (3), and "they facilitate teaching difficult and boring subjects (3), respectively. According to the opinions of social studies teachers about their rationale for using literary works in social studies courses, literary works make positive contributions to their courses in general sense. Here, particular emphasis has been placed on the facilitating effect of literary works in the teaching of history subjects, which is quite challenging. Beside this, social studies course has a theoretical structure that is based on narration, which brings about the necessity for interesting and gripping elements. At this very point, the use of literary works stands out as a preferred practice so as to fulfill this requirement.

The opinions of social studies teachers regarding their rationale for using literary works in their courses are as follows; K3: "Biographies may contribute to teaching the notion of how others' lives have the potential to influence people's lives". K15: "I am of the opinion that, they have a complementary effect on students' inadequacies particularly in historical subjects, therefore, $i$ think literary works such as stories, legends and anecdotes are likely to draw the interest of students to the course". K18: "It can help teachers turn boring and hard-to-understand abstract course subjects into more understandable and amusing ones".

\section{-Literary genres that teachers use in their courses:}

The opinions of social studies teachers regarding the literary genres they prefer to use in their courses are shown in Table 8.

Table 8. Literary genres social studies teachers prefer to use in their courses

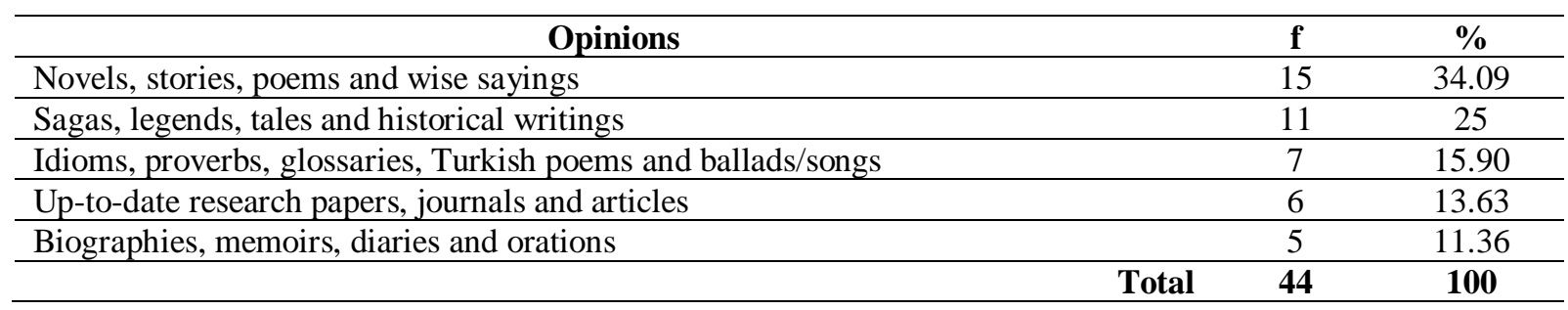

The literary genres used by social studies teachers in their courses are shown in Table 8 . As shown in the table, the most preferred genres are respectively: novels, stories, theater, poems and wise sayings (15), sagas, legends, tales and historical writings (11), idioms, proverbs, glossaries, Turkish poems and ballads/songs (7), upto-date research papers, journals and articles (6), biographies, memoirs, diaries and orations (5). As indicated in the table, novels, stories, theater and poems stand out as the most preferred genres. The leading factor underlying this situation is their being more common among the others in addition to higher accessibility. Another factor is their ability to establish empathy and a bond between the course subjects and real life experiences. Also, the comprehensive structure of these genres strengthens teacher-student communication, thus arousing student interest.

Social studies teachers stated the following opinions as to the genres they use in their course; K25: "We use the genres such as proverbs, wise sayings, sagas, poems and songs/ballads more often as this is an easier and quicker way to achieve the intended purpose for us", K19: "I rather use genres such as journal, article, and memoir, since recent information and subjects draw more interest among children”. K31: “I use the genres such as novel, memoir, travel writings, stories and songs, since exemplification of the taught subjects becomes easier this way".

\section{-Challenges that teachers encounter while using literary works in their courses:}

Participants' opinions as to the challenges that teachers encounter while using literary works in their courses are given in Table 9. 
Table 9. Challenges encountered by social studies teachers while using literary works in their courses

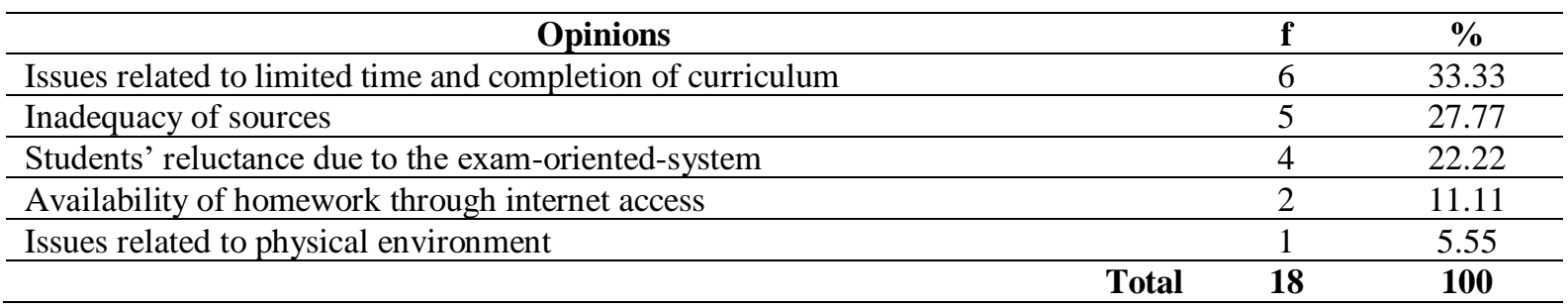

Information as to the challenges that teachers encounter while using literary works in their courses are listed in Table 9. As indicated by the table, the most preferred opinions are respectively; issues related to limited time and completion of curriculum (6), inadequacy of sources (5), students' reluctance due to the exam-orientedsystem (4), availability of homework through internet Access (2), and issues related to physical environment (1). According to social studies teachers' general opinions as to the challenges regarding the use of literary works, limited time, inadequacy of sources, and students' reluctance due to the exam-oriented-system stand out as the leading factors. Here, teachers put particular emphasis on the fact that, the problem rather stems from the different sources within the system, but not from teachers or students. Also, the inadequacy of sources related to literary works in the related curriculum and textbooks obligate teachers to use other alternatives, which unavoidably leads to unwanted situations.

Social studies teachers stated the following opinions regarding the issues they encounter while using literary works in their course; "The easy access to these genres via brief abstracts with a free-riding mentality poses a serious problem", K20: "The main issue is the insufficiency of time. The subjects taught via literary works take more time”, K23: "Spatial inadequacies for demonstrating these works and source-related issues can be stated as the main problems".

\section{-Teachers' recommendations regarding more effective use of literary works in courses:}

The responses of social studies teachers as to the recommendations for more effective use of literary works in courses are given in Table 10.

Table 10. Recommendations of social studies teachers for more effective use of literary works in courses

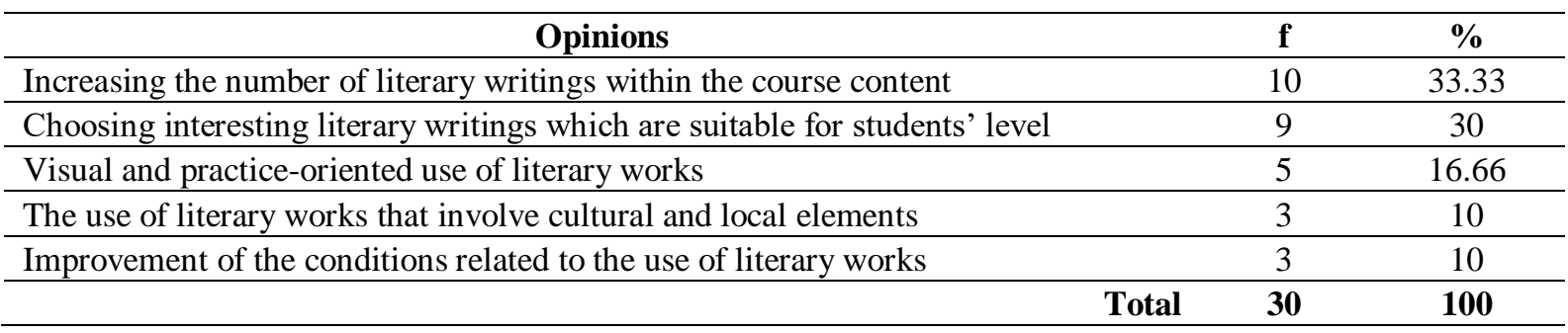

Table 10 gives the opinions of social studies teachers regarding their recommendations for a more effective use of literary works in courses. According to the table, the most preferred opinions are: increasing the number of literary writings within the course content (10), choosing interesting literary writings which are suitable for students' level (9), visual and practice oriented use of literary works (5), the use of literary works that involve cultural and local elements (3) and improvement of the conditions related to the use of literary works. The opinions of social studies teachers as to how literary works can be more effectively used in the related courses mainly involve positive and constructive ideas. Particular emphasis have been placed on taking precautions for inadequacy of sources, in addition to selection of literary writings which are more likely to draw students' interest. Also, the use of literary works in a more practice-oriented way so as to relieve students of the boring environment of the course is particularly mentioned. The necessity for the use of literary works that reflect our own culture and instill the love of country and nations, is also emphasized.

Social studies teachers stated the following opinions as to how literary works can be used more qualitatively in courses; K27: "I think that, literary works can be chosen among recent and interesting topics so as to establish connection with the taught subjects", K16: "The number of literary works can be included in the 1062 
textbook contents and these can be demonstrated via various activities", K13: "Course periods and the curriculum can be revised so as to enable extended use of literary works".

\section{Discussion, Conclusion and Recommendations}

The multidisciplinary structure of social studies course and its comprehensive content covering a vast variety of subjects have brought about the necessity to utilize the elements and sources from diverse fields. In this context, the synergy between social studies and literature, also mentioned in various studies, serves as a good example for this situation. Literary works are thus considered to make an important contribution in achievement of the aims and targets stated in the social studies curriculum. Literary works have been considered to have a facilitative effect on provision of students with the knowledge, skills, values and attitudes particularly in social studies courses. In this respect, the requirement for inclusion of literary works in course contents have been stated in the 2018 social studies curriculum and the use of such materials as a source was also recommended. This research aimed to determine the extent to which social studies teachers use "literary works" in their courses and accordingly, a total of 32 social studies teachers working in Bartın province were included as participants. The participants stated their opinions by replying the semi-structured questions under six sub-problems. Accordingly, the following conclusions are drawn:

Novels, stories, poems, theater and songs/ballads stand out as the most common genres that social studies teachers' like to follow in their daily lives. This can be associated with the popularity of literary works in society, their appealing to a vast number of people as a result of their widespread impact, and their ease of access as compared to other genres. Likewise, Yeşilbursa and Sabancı (2015) reported that, the primary preferences of social studies teachers were novels, stories and poems for use in social studies teaching, which is consistent with this finding. It can be thus inferred that, common genres that also offer variety can be expected to have a positive effect on courses through the use of diverse materials.

The general opinions of social studies teachers regarding the adequacy of literary contents in the related curriculum and textbooks indicate that they find it inadequate. According to some of the participants, the use of literary works is adequate, however the course time is limited for such use and the related samples are not sufficient. It can be inferred from such findings that, teachers attach importance to the use of literary works as a tool in their courses and they regard this in a critical manner. Sömen and Göksu (2017) also mentioned the inadequacy of the course time, and the general unsuitability of literary works for student levels. In the same study, they recommended the use of literary works that match students' general level. It can be inferred from these findings that, teachers have a common awareness as to the adequacy of literary works in textbooks.

The common rationale for social studies teachers as to the use of literary works in their courses involve its ability to facilitate teaching historical subjects, and arouse student interest and attention. At this point, the use of literary works holds great importance as it helps students in familiarizing with course contents, understanding hard-to-grasp historical subjects, thus drawing their attention to the course. Yeşilbursa and Sabanc1 (2015) stated that, social studies teachers associate literature works mostly with history among all social studies disciplines, and that literary works arouse interest in the course and draw students' attention to course subjects, which is consistent with the findings of this study. İbret et al. (2017) likewise reported that, social studies teachers mostly use literary works as a means for conveying historical subjects. It can be accordingly considered that, the use of literary works in social studies courses provide many conveniences in teaching of hard-to-teach abstract concepts.

According to the research findings, social studies teachers' general preferences for the literary genres involve novels, stories, theater, poems and wise sayings. This result shows similarity with those that social studies teachers like to follow in their daily lives. It can be accordingly inferred that, teachers' personal literary preferences also influence their choices in social studies courses. As reported by Beldağ and Aktaş (2016), social studies teachers mostly use stories, sagas, novels and novel as literary contents in their courses. Likewise, İbret et al. (2017) reported novel and story as the most commonly preferred literary genres for use in social studies courses. In another study, Sömen and Göksu (2017) reported stories and proverbs as the most commonly used literary genres in teaching of historical subjects. Ünlü (2016) also reported stories, novels and poems as the most widely used literary genres in social studies teaching. Thus, it can be considered that the use of such common literary genres that have a wide variety is more likely to draw students' interest and attention towards the course. 
According to social studies teachers' replies related to the challenges regarding the use of literary works, issues related to completion of curriculum and limited time, inadequacy of sources, and students' reluctance due to the exam-oriented-system stand out as the leading opinions. Here, participants have placed particular emphasis on the issues of time, sources, and examinations. This can be ascribed to the external factors associated with the general situation of the educational system, which may have adverse effects on the use of literary works during courses. According to Sömen and Göksu (2017), the main concerns of teachers are related to limited course periods, while Ünlü (2016) reported that teachers were mostly challenged by the difficulties in accessing literary writings.

The recommendations of social studies teachers for a more effective use of literary works in the courses mainly involve increasing the number of literary writings in course contents in parallel with course subjects, and the use of interesting literary elements that match the general level of students. Such considerations and general suggestions of teachers become more crucial at the point of establishing new curricula and selecting new textbooks for social studies teaching. At this point, the field experts that take part in the preparation of the curriculum and related textbooks are expected take teachers' recommendations into consideration as a means for establishing unity in the process of education and increasing the efficiency of courses.

Based on the research findings the following recommendations are proposed:

- Explanations as to how literary works can be efficiently used in accordance with the intended purpose can be included in the social studies curriculum and related textbooks.

- $\quad$ The types and number of literary works in social studies textbooks can be increased.

- Interesting and functional literary texts can be preferred in accordance with student levels.

- $\quad$ Source books including examples to literary genres can be prepared for social studies teaching.

- Diverse academic research can be performed based on student opinions on the use of literary genres in social studies.

\section{Acknowledgments}

This study was presented partially with the same title in $15^{\text {th }}$ International Primary Teacher Education Symposium, held by Muğla Sıtkı Koçman University in 2016. 


\title{
Sosyal Bilgiler Öğretmenlerinin Derslerinde Edebi Ürün Kullanma Durumlarının Değerlendirilmesi: Bartın Örneği
}

\author{
Giriş
}

Eğitim-öğretim, insan hayatı için temel gereksinimlerden biri olup aynı zamanda belli bir zaman dilimini kapsayan önemli bir süreci ifade etmektedir. Bu süreç dâhilinde bireyin toplum içerisinde yaşamsal ihtiyaçlarını karşılayabilmesi ve kendini ifade ederek diğer insanlarla iletişim kurabilmesi, başka bir deyişle sosyalleşmesi hususu büyük önem arz etmektedir. Çünkü insan doğası gereği sosyal bir varlıktır ve toplum içerisinde yaşamak suretiyle sosyal gereksinimlerini karşılama ihtiyacı duyar. Eğitim-öğretim sürecinde bireylerin ihtiyaç duyduğu bu gereksinimlerin karşılanmasını konu edinen çalışma alanlarının başında sosyal bilgiler dersi gelmektedir.

Sosyal Bilgiler, insanın sosyal ve fiziki çevresiyle etkileşiminin geçmiş, bugün ve gelecek bağlamında incelendiği toplu öğretim anlayışından hareketle oluşturulmuş bir ders olarak tanımlanmaktadır (MEB, 2005a). Bu manada sosyal bilgiler dersinin genel amacı; kendini ifade ederek etkin iletişim kurabilen, yaşadığı topluma etkin bir biçimde katkı sağlayan, toplumsal bilgi, beceri ve değerleri benimsemiş vatanını seven bireyler yetiştirmek şeklinde ifade edilebilir (Doğanay, 2005; Yeşilbursa ve Sabanc1, 2015).

Sosyal bilgiler birbiriyle ilişkili bilgi, beceri ve değerlerin bütünleştirilerek verildiği öğrenmeyi organize eden disiplinlerarası yapıya sahip bir derstir (MEB, 2018). Gerek sosyal olguların birbiri içerisine geçmiş olması, gerekse sosyal sorunların siyasal, toplumsal ve ekonomik bakımdan birbirinden kesin çizgilerle ayrılamaması sosyal bilgilerin çeşitli bilim dallarından yararlanmasını zorunlu kılmaktadır (Kaymakcı, 2010). Bu nedenle ders içeriğinin öğretiminde öğrencilere gerçek yaşamla bağlantı kurmalarına ve somut yaşantılar edinmelerine yardımcı olacak öğretim ortamlarının oluş̧turulması gerekmektedir ki bu durum öğrenme ortamında farklı strateji, yöntem ve teknikler ile öğretim araç ve gereçlerinin kullanılabilmesine imkan sağlasın (Meydan ve Akdağ, 2014; Yıldırım, 2017). Ayrıca dersin içeriğine yakın kültür, sanat, medya ve edebiyat gibi farklı alanlarla ilişki de kurulabilir (Akdağ, 2009). Bu alanlardan özellikle edebiyat önemli bir yer teșkil etmektedir. Çünkü edebiyat ile sosyal bilgiler birtakım benzer özelliklere sahiptir. Özellikle her ikisinin de odağında insan olması, yoğun bir okuma, yazma ve konuşma süreci içermesi, doğası gereği bir kültür aktarıcısı rolü üstlenmesi gibi nitelikler bu iki alan arasında önemli bir bağ olduğunun kanıtıdır (Akkuş, 2006; Ünlü, 2016).

Sosyal bilgiler ve edebiyat ilişkisi öğretim programlarında da kendini göstermektedir. 2005 yilından itibaren yürürlüğe giren sosyal bilgiler dersi öğretim programının "programın uygulanmasıyla ilgili açıklamalar" bölümünde yer alan iki maddede sosyal bilgiler dersinde edebi ürünlerin kullanımına ilişkin önerilere yer verilmiştir. Buna göre sosyal bilgiler öğretmenleri edebî ürünler ve yazılı materyallerden (efsaneler, destanlar, masallar, atasözleri, halk hikâyeleri, türküler ve şiirler vb.) yararlanmalı, sosyal bilgiler ile edebiyat ve coğrafyayı kaynaştırmalı, böylelikle öğrencilere vatan sevgisi kazandırmalıdır. Ayrıca sosyal bilgiler öğretmenleri öğrencilerini ders konularını sevdirici roman, tarihî roman, hikâye, hatıra, gezi yazısı, şiir ve fikra gibi edebî ürünleri okumaya teşvik etmelidir (MEB, 2005a: 6-8; MEB, 2005b: 7-10). Benzer yaklaşım 20172018 eğitim öğretim yllından itibaren yürürlüğe giren sosyal bilgiler dersi öğretim programında da sürdürülmüştür. $\mathrm{Bu}$ çerçevede sosyal bilgiler dersi öğretim programının uygulanmasında dikkat edilecek hususlar başlığı altında öğretmenlerin efsane, destan, masal, atasözü, halk hikâyesi, türkü ve şiir gibi türlerden yararlanmaları önerilerek öğrencilere dersi sevdirecek edebi ürünleri okutabilecekleri hatırlatılmıştır (MEB, 2018: 10).

Sosyal bilgiler dersinde edebi ürünlerin kullanımıyla öğrenciler birçok temel beceriyi kazanma imkânına kavuşur. Öncelikli olarak öğrenciler okuma, yazma, konuşma ve dinleme becerilerini geliştirmek suretiyle; kendilerini ifade etmeyi, iletişim ve empati kurmayı, çoklu bakış açısı kazanma ve insan kişiliğine saygı duymayı öğrenirler. Edebi ürünler aynı zamanda öğrencilerin duygu ve düşünce dünyasını geliştirmek suretiyle; duyarlılık oluşumuna, kültürel bilinçlenmeye ve demokratik kültür dokusunun sezinletilerek kazandırılmasına imkân tanır. Edebi ürünler aracılığıyla öğrencilerin anlama, kavrama, düşünme ve eleştirme yeteneği geliştirilerek hayata daha anlamlı bakmalarına ve toplumsal bir kişilik kazanmalarına katkı sağlanabilir. Ayrıca öğrencilerin ruhunu yüceltip duygularını incelterek üretkenlikleri artırabilir ve bir sanatçı hassasiyeti kazandırılarak estetik duyguları geliştirilebilir (Kuran ve Ersözlü, 2009; Öztürk ve Otluoğlu, 2002; Sever, 1998).

Edebi ürünler soyut içeriğin somutlaştırılmasını sağlar, öğrencilerin derse karşı ilgilerini artırır. Öğrencilerin ulusal ve evrensel değerleri öğrenmesine katkı sağlayarak kültürel aktarımı sağlar. Öğrencilerin hoşça vakit geçirmelerini temin ederek yaşamın içinden örnekler sunar (Akkuş, 2007; Chapin ve Messick, 1999; Çencen, 2010; Garcia ve Michaelis, 2001; Köksal, 2010; Tekgöz, 2005; Turk ve diğ., 2007; Oğuzkan, 2001; Öztürk ve 
Otluoğlu, 2010; Top, 2009; akt. Kaymakc1, 2013). Böylelikle öğrencilerin düşünme becerilerini geliştirerek güncel konuların öğretimi, örnek olayların yorumlanması ve günümüz olayları ile tarihsel olaylar arasında karşılaştırmalar yaparak gerçeği farketme noktasında onlara kolaylıklar sağlar (Altun ve Ata, 2008; Çengelci, 2013; Dönmez ve Altıkulaç 2014). Öğrencilerin sosyal bilgiler dersinin odağında bulunan "geçmiş, şimdi ve gelecek" kavramları ile "değişim, gelişim ve süreklilik" kavramları arasında bağlantı kurarak aralarındaki ilişkiyi keşfetmelerine/analiz etmelerine olanak sağlar (Kaya ve Ekiçi, 2015; Krey, 1998). Yaşamlarıyla ve yaptıklarıyla ün kazanmış kişilerin öğrencilere rol model olmasında ve bu kişilerin nezdinde öğrencilerin belli değerleri kazanmalarına da katkı sağlar (Er ve Şahin, 2012).

Sosyal bilgiler öğretimiyle ilişkisi bu denli yakın olan ve dersin öğretiminde önemli bir yeri olan edebi ürünlerin sosyal bilgiler ve sosyal bilgiler konu içeriğinde yer alan derslerde kullanımına yönelik birtakım araştırmalar yapılmıştır. Araştırmaların sonucunda derslerde edebi ürün kullanımının öğrencilerin akademik başarılarını artırdığı (Akkuş, 2007; Altunay-Şam, 2011; Altunay-Şam ve İskender-Kılıç, 2011; Arslan, 2014; Bacak, 2008; Bölücek, 2008; Çifçi, 2011; Erdem, 2010; Gevenç, 2014; Keskin, 2008; Öztürk, 2002; Şimşek, 2000; Tekgöz, 2005; Top, 2009; Yeşilbursa ve Sabanc1, 2015; Yiğit, 2007), tarihsel düşünme becerilerini ve yaratıcılıklarını geliştirdiği (Bacak, 2008; Erdoğan, 2007), empati eğiliminin gelişimine katkı sağladığı (Akyol, 2011), derse karşı olumlu tutum geliştirdiği (Demir, 2011; Oruç ve Erdem, 2010; Öztürk ve Otluoğlu, 2002; Top, 2009) görülmüştür. Buna ilaveten ders kitaplarında edebi ürünlerin yerinin ele alındığı araştırmalar da (Kaymakc1, 2012; Kaymakc1, 2013; Kaymakcı ve Er, 2013; Oruç, 2009; Yeşilbursa, Sabancı ve Hamarat, 2013) mevcuttur. Ayrıca araştırmalarda öğrencilerin (Çencen, 2017; Er, 2008; Er, 2010; Er ve Şahin, 2012; Kaymakcı, 2008; Şimşek, 2006a; Şimşek, 2006b), öğretmen adaylarının (Beldağ ve Aktaş, 2016; Dönmez ve Altıkulaç, 2014; Tokdemir, 2016; Ünlü ve Kaşkaya, 2018; Yeşilbursa ve Sabanc1, 2015) ve öğretmenlerin görüşlerine de (Beldağ ve Aktaş, 2016; Çencen ve Akça-Berk, 2014; İbret, Karasu-Avc1, Karabıyık, Güleş ve Demirci, 2017; Mertol, 2008; Şimşek, 2006a; Topçu ve Kaymakc1, 2018; Ünlü, 2016; Yıldırım, 2017) başvurulmuştur.

Sosyal bilgiler edebi ürün ilişkisini konu edinen ve öğretmenlerin görüşlerini ele alan araştırmalar incelendiğinde Beldağ ve Aktaş'ın araştırmasında (2016) öğretmenlerin ve öğretmen adaylarının sosyal bilgiler dersinde edebî eser kullanımına ilişkin görüşleri incelenmiştir. Rize ilinde toplam 48 kişinin (24'ü sosyal bilgiler öğretmeni, 24'ü de sosyal bilgiler öğretmen adayı) katılımıyla gerçekleştirilen araştırmada sosyal bilgiler öğretiminde kullanılan/kullanılabilecek edebî eser türü, bunların taşıması gereken nitelikler, edebi eserlerin hangi öğrenme alanında kullanılabileceği ile eser isimlerine odaklanılmıştır.

Çencen ve Akça-Berk tarafından yapılan araştırmada (2014), öğretmenlerin bir edebi ürün olarak şiirin kullanımına ilişkin görüşleri belirlenmiştir. Bu bağlamda öğretmenlerin derslerinde şiir kullanımına yönelik düşünceleri bazı değişkenler (cinsiyet, çalışmakta oldukları okul türleri, meslekî kıdemleri ile en son mezun oldukları okul) açısından incelenmiştir.

İbret, Karasu-Avcı, Karabıyık, Güleş ve Demirci tarafından yapılan araştırmada (2017) öğretmenlerin değer öğretiminde edebi ürünleri kullanma durumları incelenmiştir. Araştırma kapsamında değerler öğretiminde edebi ürünlerin kullanılmasının önemi, değerler öğretiminde edebi ürünlerin kullanılma durumu, değer öğretiminde kullanılan edebi ürünler ile değer öğretiminde edebi ürünlerin kullanılmasının derse olan katkıları gibi konular üzerinde durulmuştur.

Mertol'un araştırmasında (2008), öğretmenlerin derslerinde çocuk edebiyatı ürünlerinden yararlanma durumları ele alınmıştır. Bu doğrultuda öğretmenlerin görüşlerinin çeşitli değişkenler (cinsiyet, asıl branş ve mesleki kıdem) açısından gösterdiği farklılıklar incelenmiş, öğretmenlerin çocukluk yıllarında okudukları çocuk romanları belirlenmeye çalışılmıştır.

Şimşek tarafından yapılan araştırmada (2006a) tarihsel romanların derslerde kullanımına yönelik öğrenci (223 kişi) ve öğretmen görüşleri (30 kişi) incelenmiştir. Bu kapsamda öğrencilerin tarihsel romana ilişkin görüşleri çeşitli değişkenler (okul, cinsiyet, okudukları sınıf seviyesi ve tarih konulu film izleme durumları) açısından ve öğretmenlerin tarihsel romana ilişkin görüşleri çeşitli değişkenler (cinsiyet, mezun olduğu okul, hizmet süreleri (kıdem), kitap okuma durumları ve süreli yayın takip etme durumları) açısından karşılaştırılmıştır.

Topçu ve Kaymakcı'nın araştırmalarında (2018), öğretmenlerin derslerinde menkıbelerden yararlanma durumu ele alınmıştır. Bu doğrultuda öğretmenlerin menkıbelerin tanımına ve eğitimsel yararına ilişkin görüşleri, sosyal bilgiler öğretim programı ve ders kitaplarında menkıbelerin yerine ilişkin görüşleri, derslerinde 
menkıbe kullanımıyla ilgili yeterlilik düzeyleri ve derslerinde menkıbelerin kullanımına ilişkin görüşleri araştırılmıştır.

Ünlü tarafindan yapılan araştırmada (2016), öğretmenlerin ders materyali olarak edebi ürün kullanımına yönelik görüşleri incelenmiştir. Erzincan ilinde toplam 20 kişinin katılımıyla gerçekleştirilen araştırmada öğretmenlerin hangi edebi ürünleri, niçin tercih ettikleri, edebi ürün seçerken kullandıkları ölçütler, hangi konuların öğretiminde ve dersin hangi aşamasında edebi ürünleri kullandıkları gibi hususlar üzerinde durulmuştur.

Yıldırım'ın araştırmasında ise (2017), öğretmenlerin edebi ürünleri kullanma durumlarını ve varsa sorunlarını ortaya koymak istenmiştir. Erzurum ilinde toplam 20 öğretmenin katılımıyla gerçekleştirilen araştırmada, öğretmenlerin derslerinde edebi ürün kullanım durumları, edebi ürünleri kullanma amaçları, seçerken kullandıkları ölçütler, derslerinde ne tür edebi ürünleri kullandıkları, bunları nasıl temin ettikleri, derslerinde edebi ürünleri nasıl kullandıkları ile derslerinde edebi ürün kullanırken karşılaştıkları sorunlar gibi konular araştırılmıştır.

Alanda yapılan bu çalışmalar değerlendirildiğinde çalışmalardan bir bölümünün genel olarak edebi ürün kullanımına yönelik olduğu (Beldağ ve Aktaş, 2016; Ünlü, 2016; Yıldırım, 2017), bir bölümünün çocuk edebiyatı ürünlerini ele aldığı (Mertol, 2008), bir bölümünün edebi türlere odaklandığı (Çencen ve Akça-Berk, 2014; Şimşek, 2006a; Topçu ve Kaymakcı, 2018) ve bir bölümünün de değer öğretimi ile edebi ürün kullanımını ilişkilendirmeye çalıştığ (İbret, Karasu-Avcı, Karabıyık, Güleş ve Demirci, 2017) görülmektedir. Öte yandan genel olarak edebi ürün kullanımına odaklanan araştırmalardan birinin Rize'de (Beldağ ve Aktaş, 2016), birinin Erzincan'da (Ünlü, 2016) ve birinin de Erzurum'da (Yıldırım, 2017) gerçekleştirildiği anlaşılmaktadır. Bu araştırmaların nitel metodoloji kullanılarak yapılması nedeniyle sadece ilgili bölgede görev yapan örneklem grubunu içermesi ve onların görüşlerini yansıtması başka bölgelerde öğretmenlerin edebi ürünlerden yararlanma durumuna ilişkin bir araştırmaya olan ihtiyacı gündeme getirmektedir. Yapılacak bu araştırmayla alandaki araştırmalara çeşitlilik sağlanacak, ileriki aşamalarda yapılacak araştırmalar için ise ihtiyaç durumu ortaya konulmuş olacaktır.

\section{Amaç}

$\mathrm{Bu}$ araştırmanın amacı sosyal bilgiler öğretmenlerinin derslerinde edebi ürün kullanma durumlarını ortaya koymaktır. Araştırmada aşağıdaki sorulara cevap aranmıştır:

1. Öğretmenlerin günlük hayatta takip etmekten hoşlandıkları edebi ürünler nelerdir?

2. Öğretmenlerin edebi ürünlerin sosyal bilgiler öğretim programı ve ders kitaplarındaki yeriyle ilgili görüşleri nelerdir?

3. Öğretmenlerin derslerinde edebi ürünleri kullanma gerekçeleri nelerdir?

4. Öğretmenlerin derslerinde kullandıkları edebi ürün türleri nelerdir?

5. Öğretmenlerin derslerinde edebi ürün kullanırken karşlaştıkları zorluklar nelerdir?

6. Öğretmenlerin derslerde edebi ürünlerin daha etkili kullanılabilmesi için yaptıkları öneriler nelerdir?

\section{Yöntem}

Araştırma doğası gereği nitel bir anlayışla desenlenmiştir. Bilindiği gibi nitel araşıtırma, araştırma öznelerinin bakış açılarını, anlam dünyalarını ve buna ilişkin olay ve durumları öznelerinin gözüyle doğal ortamda gerçekçi ve bütüncül bir biçimde ortaya koymaya çalışır (Yıldırım ve Şimşek, 2011; Kuş, 2012). Araştırmada öğretmenlerin konuya yönelik geçmiş deneyimlerini öğrenmek, konuyu nasıl algıladıklarını, yorumladıklarını ortaya koymak (Patton, 2014) ve araştırmanın amacına uygunluğu nedeniyle nitel metodoloji kapsamında olgubilimden yararlanılmıştır.

\section{Çalışma Grubu}

Araştırmanın çalışma grubunu, 2015-2016 eğitim-öğretim yılı bahar yarıyılında Bartın ilinde görev yapan 32 sosyal bilgiler öğretmeni oluşturmaktadır. Çalışma grubu oluşturulurken, amaçlı örnekleme yöntemlerinden uygun örnekleme yöntemi tercih edilmiştir. Araştırmaya ilişkin bu örnekleme yönteminin tercih edilmesinin sebebi, araştırmaciya zaman, para, emek ve katılımcılara ulaşılabilirlik noktasında kolaylık sağlaması gibi özelliklerinden kaynaklanmaktadır (Patton, 2014). 
Araştırmanın çalışma grubunun belirlenmesi sürecinde öncelikle gerekli izinler alınmıştır. Gerekli izinler alındıktan sonra okullara gidilmiş, araştırmanın amacı, veri toplama aracı ve verilerin nasıl analiz edileceği gibi hususlar sosyal bilgiler öğretmenlerine açıklanmış, veri toplama sürecine katılmak isteyen öğretmenlerle araştırma gerçekleştirilmiştir. Araştırmaya katılan sosyal bilgiler öğretmenlerine ilişkin demografik bilgiler aşağıda açıklanmıştır:

Tablo 1. Öğretmenlerin cinsiyetlerine ilişkin bilgiler

\begin{tabular}{lccc}
\hline & Cinsiyet & n & \% \\
\hline Kadın & & 14 & 43.75 \\
Erkek & & 18 & 56.25 \\
\hline & Toplam & $\mathbf{3 2}$ & $\mathbf{1 0 0}$ \\
\hline
\end{tabular}

Tablo 1'de öğretmenlerin cinsiyetlerine ilişkin bilgiler verilmiştir. Tablodan öğretmenlerin \%43.75'inin kadın, \%56.25'inin erkek olduğu anlaşılmaktadır. Buradan hareketle öğretmenlerin cinsiyet açısından birbirine yakın bir dağılıma sahip olduğu söylenebilir.

Tablo 2. Öğretmenlerin mesleki deneyimlerine ilişkin bilgiler

\begin{tabular}{lcc}
\hline \multicolumn{1}{c}{ Mesleki Deneyim } & n & \% \\
\hline $1-5$ Yil & 5 & 15.63 \\
$6-10$ Yil & 6 & 18.75 \\
$11-15$ Y1 & 8 & 25.00 \\
$16-20$ Y1 & 9 & 28.12 \\
20 Yil ve Üzeri & 4 & 12.50 \\
\hline \multicolumn{1}{c}{ Toplam } & $\mathbf{3 2}$ & $\mathbf{1 0 0}$ \\
\hline
\end{tabular}

Öğretmenlerin mesleki deneyimlerine ilişkin bilgiler Tablo 2'de açıklanmıştır. Tabloya göre öğretmenlerin \%15.63'ü 1-5 y1l, \%18.75'i 6-10 y1l, \%25'i 11-15 yıl, \%28.12'si 16-20 yıl ve \%12.50'si 20 yıl ve üzeri mesleki deneyime sahiptir. Buradan hareketle öğretmenlerin çoğunluğunun mesleki deneyim açısından diğerlerine göre daha tecrübeli olduğu söylenebilir.

Tablo 3. Öğretmenlerin mezun oldukları programlara ilişkin bilgiler

\begin{tabular}{|c|c|c|}
\hline Program Türü & $\mathbf{n}$ & $\%$ \\
\hline Sosyal Bilgiler Öğretmenliği & 13 & 40.63 \\
\hline Tarih Öğretmenliği & 9 & 28.12 \\
\hline Coğrafya Öğretmenliği & 6 & 18.75 \\
\hline Diğer & 4 & 12.50 \\
\hline Toplam & 32 & 100 \\
\hline
\end{tabular}

Tablo 3'te öğretmenlerin mezun oldukları program türüne ilişkin bilgiler ele alınmıştır. Tablodan öğretmenlerin \%40.63'ünün sosyal bilgiler, \%28.12'sinin tarih, \%18.75'inin coğrafya ve \%12.50'sinin diğer alanlardan (sınıf öğretmenliği, tarih, coğrafya vb.) mezun oldukları anlaşılmaktadır. Buradan hareketle katılımcılarının çoğunluğunun eğitim fakültesi mezunu ve sosyal bilgiler öğretmenliği programı mezunu öğretmenlerden oluştuğu söylenebilir.

\section{Veri Toplama Aracı ve Geliştirilmesi}

Araştırmanın veri toplama aracı olarak yapılandırılmış mülakattan yararlanılmıştır. Araştırmada yapılandırılmış mülakat, katılımcıların verdiği bilgiler arasındaki benzer ve farklı yönleri belirlemeye olanak tanıması ve bunlar arsında karşılaştırmalar yapmayı sağlaması gibi özellikleri nedeniyle tercih edilmiştir (Yıldırım ve Şimşek, 2011).

Veri toplama aracının geliştirilme sürecinde öncelikle alanyazın kapsamlı bir şekilde taranarak yapılan araştırmalar incelenmiştir. İkinci aşamada taslak mülakat formu hazırlanmıştır. İki bölümden oluşan mülakat formunun ilk bölümünde katılımcıların demografik bilgilerini öğrenmeye yönelik sorular sorulmuştur. Formun ikinci bölümünde ise sosyal bilgiler öğretmenlerinin günlük hayatta takip etmekten hoşlandıkları edebi ürünler, 
derslerinde kullandıkları edebi ürün türleri, edebi ürün kullanımı esnasında karşılaştıkları durumlar, kullandıkları edebi ürünlerin konuların öğretimine nasıl katkı sağladığı ve edebi ürünlerin nasıl daha nitelikli kullanılabileceğine ilişkin görüşlerini almak üzere oluşturulan sorulara yer verilmiştir. Bu çerçevede oluşturulan mülakat formu sosyal bilgiler eğitimi alan uzmanı iki akademisyen, bir sosyal bilgiler öğretmenliği programı mezunu bir öğretmen ile dil ve anlatım açısından kontrol etmesi amacıyla bir Türkçe dersi öğretmenine inceletilmiştir. Daha sonra uygulama sürecinde yer almayan üç sosyal bilgiler öğretmeni ile bir ön uygulama gerçekleştirilmiş ve ortaya çıkan görüşler doğrultusunda mülakat formuna son hali verilmiştir.

\section{Verilerin Toplanması}

Araştırma verileri 01 Ocak-01 Mart 2016 tarihleri arasında Bartın il merkezine bağlı okullarda görev yapan ve araştırmaya gönüllü olarak katılmak isteyen sosyal bilgiler öğretmenlerinden toplanmıştır. Veri toplama süreci yüzyüze görüşmeler yapılarak yürütülmüş, öğretmenlerin düşünceleri not tutmak suretiyle kaydedilmiştir.

\section{Verilerin Analizi}

Araştırma kapsamında toplanan veriler içerik analizi yardımıyla çözümlenmiştir. Araştırmada içerik analizi; bireylerin ilgilerini belirleme firsatı sunması, verilerin içindeki belli kelime ve kavramların varlığını, anlamlarını ve ilişkilerini belirleme olanağı sağlaması ve veri analizinde sayısallaştırmaya imkân tanıması gibi özellikleri nedeniyle kullanılmıştır (Büyüköztürk, Kılıç-Çakmak, Akgün, Karadeniz ve Demirel, 2008).

Araştırmanın veri analizi sürecinde öncelikle kodlamalar yapılmış, sonrasında kategoriler ve temalar belirlenerek frekans ve yüzde olarak tablolaştırılmıştır. Veri analizinin geçerliğini sağlama adına temaları temsil edecek şekilde öğretmen görüşlerinden doğrudan alıntılar yapılmıştır. Veri analizinin güvenirliğini sağlama adına ise araştırmacı üçgenlemesi (Patton, 2014) yapılmıştır. Veriler araştırmacılar tarafından ayrı ayrı analiz edilmiştir. Yapılan analizler Miles ve Huberman'ın (1994) ortaya koyduğu güvenirlik formülü aracılığıyla hesaplanmış, uyuşum yüzdesinin de \%84.73 olduğu tespit edilmiştir. Bu bağlamda araştırmacıların uyuştukları veriler bulgularda gösterilmiş, uyuşum sağlanamayan veriler tasnif dışı bırakılmıştır. Ayrıca veri analizinde gizlilik boyutuna dikkat edilmiş, veri toplama sürecine katılan öğretmenlerin isimlerini gizlemek amacıyla gerçek isimlerin yerine takma isimler (K-1, K-2 vb.) kullanılmıştır.

\section{Bulgular ve Yorum}

Sosyal bilgiler öğretmenlerinin derslerinde edebi ürün kullanma durumlarını değerlendirilmesini amaçlayan bu araştırmada aşağıdaki bulgulara ulaşılmıştır:

\section{- Öğretmenlerin günlük hayatta takip etmekten hoşlandıkları edebi ürünler:}

Sosyal bilgiler öğretmenlerinin günlük hayatta takip etmekten hoşlandıkları edebi ürünlere ilişkin cevaplar Tablo 4'de verilmiştir.

Tablo 4. Sosyal bilgiler öğretmenlerinin günlük hayatta takip etmekten hoşlandıkları edebi ürünler

\begin{tabular}{|c|c|c|}
\hline Görüşler & f & $\%$ \\
\hline Roman, hikaye, şiir, tiyatro ve şark1/türkü & 14 & 45.16 \\
\hline Makale, sosyo-politik yazılar ve güncel dergiler & 8 & 25.80 \\
\hline Tarihi eserler, destan, biyografi ve anılar & 7 & 22,58 \\
\hline Coğrafi dergiler ve gezi yazıları & 2 & 6,45 \\
\hline & 31 & 100 \\
\hline
\end{tabular}

Tablo 4'de görüldüğü üzere sosyal bilgiler öğretmenlerinin günlük hayatta takip etmekten hoşlandığ1 edebi ürünlere ilişskin bilgilere ver verilmiştir. Tablo incelendiğinde en fazla tercih edilen edebi ürünler sırasıyla; roman, hikaye, şiir, tiyatro ve şarkı/türkü (14), makale, sosyo-politik yazılar ve güncel dergiler (8), tarihi eserler, destan, biyografi ve anılar (7) ve coğrafi dergiler ve gezi yazıları (2) şeklindedir. Sosyal bilgiler öğretmenlerinin günlük hayatta takip etmekten hoşlandığı edebi ürünlere genel olarak bakıldığında, çoğunlukla klasik manada edebi türlerin temelini oluşturan roman, hikaye ve şiir gibi unsurların ön plana çıktığı görülmektedir. Bu durum bu edebi ürünlerin kendi alanı içinde hala ağırlığını koruduğu ve öğretmenlerinde düzenli okuma alışkanlığına yönelik bir eğiliminin olduğu şeklinde değerlendirilebilir. Tiyatro ve şark1/türkü gibi göze kulağa hitap eden ve insanı duygusal anlamda etkileyebilecek türlerinde tercih edilmesi, öğretmenlerin bunları yaşamlarında bir 
ihtiyaç olarak gördükleri şeklinde yorumlanabilir. Diğer edebi türlerin nispeten daha az tercih edilmesi ve birbirine yakın oranda olması da genel manada kabul gördüklerini ancak öğretmenler tarafindan sürdürülebilir bir takip düzeyine ulaşamadığı şeklinde değerlendirilebilir.

Sosyal bilgiler öğretmenleri günlük hayatta takip etmekten hoşlandığı edebi ürünler ile ilgili olarak K5: "Daha çok roman, hikaye, makale ve çeşitli araştırma yazllarını takip etmekten hoşlanırım”, K13: "Özellikle boş zamanlarımda tarihi roman, biyografi ve şiir kitapları okumaktan büyük zevk alıyorum”, K11: "Güncel dergiler ile süreli yayınlar ve gündeme ilişkin makaleler dikkatimi çeken ve okuduğum edebi metinlerdir" şeklinde görüşlerini belirtmiş̧lerdir.

-Öğretmenlerin edebi ürünlerin sosyal bilgiler öğretim programı ve ders kitaplarındaki yeriyle ilgili görüşleri:

Sosyal bilgiler öğretmenlerinin edebi ürünlerin sosyal bilgiler öğretim programı ve ders kitaplarındaki yeterliliğine ilişkin olumlu ve olumsuz görüşlere ait cevaplar Tablo 5 ve 6' da verilmiştir.

Tablo 5. Sosyal bilgiler öğretmenlerinin edebi ürünlerin sosyal bilgiler öğretim programı ve ders kitaplarındaki yeterliliğine ilişkin olumlu görüşleri

\begin{tabular}{lccc}
\hline \multicolumn{1}{c}{ Görüssler } & f & \% \\
\hline Yeterli & 5 & 38.46 \\
\hline Yeterli, ancak ders süresinin yeterli olmaması & 5 & 38.46 \\
\hline Yeterli, ancak konuya ilişkin örneklerin yetersiz olması & 3 & 23,07 \\
\hline & Toplam & $\mathbf{1 3}$ & $\mathbf{1 0 0}$ \\
\hline
\end{tabular}

Tablo 5'de görüldüğü üzere sosyal bilgiler öğretmenlerinin edebi ürünlerin sosyal bilgiler öğretim programı ve ders kitaplarındaki yeterliliğine ilişkin olumlu görüşlerine ver verilmiştir. Tabloya bakıldığında en fazla tercih edilen görüşler sırasıyla; yeterli (5), yeterli, ancak ders süresinin yeterli olmaması (5), yeterli, ancak konuya ilişkin örneklerin yetersiz olması (3) şeklindedir. Sosyal bilgiler öğretmenlerinin edebi ürünlerin sosyal bilgiler öğretim programı ve ders kitaplarındaki yeterliliğine ilişkin olumlu görüşlerine genel olarak bakıldığında, edebi ürün kullanımını yeterli görüp, ders süresini ve ilgili örnekleri yetersiz görmeleri öğretmenlerin konuya gösterdikleri hassasiyet bakımından önemlidir. Bu durum özellikle edebi ürünlerin derste sağlıklı bir şekilde kullanılabilmesi ve öğrenci açısından verimli olabilmesi açısından büyük önem taşımaktadır.

Sosyal bilgiler öğretmenlerinin edebi ürünlerin sosyal bilgiler öğretim programı ve ders kitaplarındaki yeterliliğine ilişkin olumlu olarak K12: "Yeterli olduğunu söyleyebilirim fakat örnek çeşitliliğinin az olduğunu düşünüyorum”, K3: "Yeterli görmeme rağmen ders saatinin bunlara yetmediği çok açıktır. Bundan dolayı birçok edebi ürünü ders ortamına getiremiyoruz” biçiminde görüşlerini ifade etmişlerdir.

Tablo 6. Sosyal bilgiler öğretmenlerinin edebi ürünlerin sosyal bilgiler öğretim programı ve ders kitaplarındaki yeterliliğine ilişkin olumsuz görüşleri

\begin{tabular}{lccc}
\hline & Görüsşler & f & \% \\
\hline Yeterli değil & 15 & 71.42 \\
\hline Yeterli değil, diğer derslerle ilişkilendirme yapılması & 6 & 28.57 \\
\hline & Toplam & $\mathbf{2 1}$ & $\mathbf{1 0 0}$ \\
\hline
\end{tabular}

Tablo 6'da görüldüğü üzere sosyal bilgiler öğretmenlerinin edebi ürünlerin sosyal bilgiler öğretim programı ve ders kitaplarındaki yeterliliğine ilişkin olumsuz görüşlerine ver verilmiştir. Tabloya bakıldığında en fazla tercih edilen görüşler sırasıyla; yeterli değil (15), yeterli değil, diğer derslerle ilişkilendirme yapılması (6) şeklindedir. Sosyal bilgiler öğretmenlerinin edebi ürünlerin sosyal bilgiler öğretim programı ve ders kitaplarındaki yeterliliğine ilişkin olumsuz görüşlerine genel olarak bakıldığında, çoğunlukla yeterli görülmediği ve gerçek manada derse yansıtılamadığı ifade edilmektedir. Bu durum öğretmenlerin edebi ürün kullanımına yönelik olumlu bir düşünceye sahip olduklarının bir göstergesi olarak kabul edilebilir. Özellikle diğer derslerle ilişkilendirme yapmaları da bu görüşü destekler niteliktedir.

Sosyal bilgiler öğretmenlerinin edebi ürünlerin sosyal bilgiler öğretim programı ve ders kitaplarındaki yeterliliğine ilişkin olumsuz olarak K22: "Edebi eserlere yeterince yer verilmediğini düşünüyorum, ancak kendi 
çabalarımızla getirdiğimiz kaynakları kullanıyoruz", K8: "Yeterli görmüyorum ancak Türkçe dersi ile ilişskilendirme yaparak değerlendiriyoruz" biçiminde görüşlerini ifade etmişlerdir.

\section{-Öğretmenlerin derslerinde edebi ürünleri kullanma gerekçeleri:}

Sosyal bilgiler öğretmenlerinin derslerinde edebi ürünleri kullanma gerekçelerine ilişkin cevaplar Tablo 7'de verilmiştir.

Tablo 7. Sosyal bilgiler öğretmenlerinin derslerinde edebi ürünleri kullanma gerekçeleri

\begin{tabular}{lccc}
\multicolumn{1}{c}{ Görüsşler } & f & \% \\
\hline Tarih konularının anlaşılmasını kolaylaşıması & 8 & 32 \\
\hline Derse olan ilgi ve merakı arttırması & 7 & 28 \\
\hline Öğrenciler üzerinde etki uyandırması & 4 & 16 \\
\hline Soyut bilgileri somutlaştırması & 3 & 12 \\
\hline Zor ve sıkıcı konuların öğretimine katkı sağlaması & 3 & 12 \\
\hline & Toplam & $\mathbf{2 5}$ & $\mathbf{1 0 0}$ \\
\hline
\end{tabular}

Tablo 7'de görüldüğü üzere sosyal bilgiler öğretmenlerinin derslerinde edebi ürünleri kullanma gerekçeleri ilişkin görüşlerine ver verilmiştir. Tabloda görüldüğü şekliyle en fazla tercih edilen görüşler sırasıyla; tarih konularının anlaşıımasını kolaylaştırması (8), derse olan ilgi ve merakı arttırması (7), öğrenciler üzerinde etki uyandırması (4), soyut bilgileri somutlaştırması (3) ve zor ve sıkıcı konuların öğretimine katkı sağlaması (3) şeklindedir. Sosyal bilgiler öğretmenlerinin derslerinde edebi ürünleri kullanma gerekçeleri ilişkin görüşleri genel manada değerlendirildiğinde, öğretim sürecine olumlu manada katkılar yaptığı belirtilmiştir. Burada özellikle anlaşılması zor, öğretiminde güçlük çekilen tarih konularının öğretiminde edebi ürünlerin kolaylaştırıcı bir etkide bulunduğu üzerinde durulmuştur. Bunun yanında sosyal bilgiler dersinin anlatıma dayalı teorik bir yapıya sahip olması nedeniyle ilgi arttırıcı ve dikkat çekici unsurlara ihtiyaç duyulmaktadır. Edebi ürünlerinde bu ihtiyacı karşılar nitelikte derste kullanılması öğretmenler tarafından tercih edilen bir durum olarak karşımıza çıkmaktadır.

Sosyal bilgiler öğretmenlerinin derslerinde edebi ürünleri kullanma gerekçelerine ilişkin olarak K3: "Biyografi türü ürünlerde başka kişilerin hayatlarının insanları nasıl etkileyebileceğini öğretme konusunda katkı sağlayabilir", K15: "Özellikle öğrencilerin tarih konularında ki eksik bilgilerini tamamlayıcı şekilde katkısı olacağ kanaatindeyim. Bu nedenle hikaye, efsane, fikra gibi edebi ürünlerin derse olan merakı arttıracağını düşünüyorum", K18: "Slkıcı ve anlaşılmazı zor soyut konuların bir parça da olsa daha anlaşılabilir ve zevkli hale gelmesinde yardımcı olabilir" şeklinde görüşlerini ifade etmişlerdir.

\section{-öğretmenlerin derslerinde kullandlkları edebi ürün türleri:}

Sosyal bilgiler öğretmenlerinin derslerinde kullandıkları edebi ürün türlerine ilişkin görüşlerine ait cevaplar Tablo 8'de verilmiştir.

Tablo 8. Sosyal bilgiler öğretmenlerinin derslerinde kullandıkları edebi ürün türleri

\begin{tabular}{lccc}
\multicolumn{1}{c}{ Görüssler } & f & \% \\
\hline Roman, hikaye, tiyatro, şiir ve özlü sözler & 15 & 34.09 \\
\hline Destan, efsane, masal ve tarihi metin & 11 & 25 \\
\hline Deyim, atasözü, sözlük, mani ve türkü/şark1 & 7 & 15.90 \\
\hline Güncel araştırma yazıları, dergi ve makale & 6 & 13.63 \\
\hline Biyografi, anı, günlük ve nutuk & 5 & 11.36 \\
\hline & Toplam & $\mathbf{4 4}$ & $\mathbf{1 0 0}$ \\
\hline
\end{tabular}

Tablo 8'de görüldüğü üzere sosyal bilgiler öğretmenlerinin derslerinde kullandıkları edebi ürünlere ilişkin bilgilere ver verilmiştir. Tabloya bakıldığında en fazla tercih edilen edebi ürünler sırasıyla; roman, hikaye, tiyatro, şiir ve özlü sözler (15), destan, efsane, masal ve tarihi metin (11), deyim, atasözü, sözlük, mani ve türkü/şarkı (7), güncel araştırma yazıları, dergi ve makale (6) ve biyografi, anı, günlük ve nutuk (5) şeklindedir. Sosyal bilgiler öğretmenlerinin derslerinde kullandıkları edebi ürünlere genel olarak bakıldığında, roman, 
hikaye, tiyatro ve şiir türlerinin ön plana çıktığı görülmektedir. Ardından destan, efsane, masal ve tarihi metin türler gelmektedir. Bu türlerin tercih edilmesinde ki faktörlerin başında diğer türlere oranla daha yaygın olmaları ve ulaşılabilirlikte ki kolaylıklar ifade edilebilir. Diğer bir faktörde çocukların bu türler aracılığıyla empati kurabilmesi ve konulara ilişkin yaşanmışlıklar, tecrübeler noktasında bir bağ oluşturabilme kolaylığıdır. Ayrıca bu türlerin kapsamlı bir yapı arz etmesi, öğretmen-öğrenci iletişimini güçlendirmekte ve öğrencinin derse olan ilgisini arttırabilmektedir.

Sosyal bilgiler öğretmenleri derslerinde kullandıkları edebi ürünler ile ilgili olarak K25: “Atasözü, özdeyiş, destan, şiir ve şarkl/türkü türlerini daha çok kullanıyoruz. Çünkü bunlarla istenilen amaca daha klsa yoldan ve hızlı bir şekilde ulaşabiliyoruz”, K19: “Dergi, makale anı türü örnekleri kullanıyorum. Çünkü yeni bilgiler ve konular ögrrencilerin daha çok ilgisini çekiyor", K31: "Roman, anı, gezi yazlları, hikaye, şarkı gibi ürünleri kullanıyorum. Işslediğimiz konulardaki örnekleri bahsettiğim edebi eserlerde rahatlıla bulabiliyorum" biçiminde düşüncelerini belirtmişlerdir.

\section{-Ö̆̆retmenlerin derslerinde edebi ürün kullanırken karşılaştıkları zorluklar:}

Sosyal bilgiler öğretmenlerinin derslerinde edebi ürün kullanırken karşılaştıkları zorluklara ilişkin görüşlere ait cevaplar Tablo 9'da verilmiştir.

Tablo 9. Sosyal bilgiler öğretmenlerinin derslerinde edebi ürün kullanırken karşılaştıkları zorluklar

\begin{tabular}{lccc}
\hline \multicolumn{1}{c}{ Görüşler } & f & \% \\
\hline Program yetiştirme ve zaman kaygısı & 6 & 33.33 \\
\hline Kaynak yetersizliği & 5 & 27.77 \\
\hline Sinav odaklı sistemden dolayı öğrencilerin soğuk bakması & 4 & 22.22 \\
\hline Öğrencilerin ödevlere internet üzerinde ulaşması & 2 & 11.11 \\
\hline Fiziksel ortamdan kaynaklanan sorunlar & 1 & 5.55 \\
\hline & Toplam & $\mathbf{1 8}$ & $\mathbf{1 0 0}$ \\
\hline
\end{tabular}

Tablo 9'da görüldüğü üzere sosyal bilgiler öğretmenlerinin derslerinde edebi ürün kullanırken karşılaştıkları zorluklara ilişsin bilgilere ver verilmiştir. Tablo incelendiğinde en fazla tercih edilen görüşler sırasıyla; programı yetiştirme ve zaman kaygısı (6), kaynak yetersizliği (5), sınav odaklı sistemden dolayı öğrencilerin soğuk bakması (4), öğrencilerin ödevlere internet üzerinde ulaşması (2) ve fiziksel ortamdan kaynaklanan sorunlar (1) şeklindedir. Sosyal bilgiler öğretmenlerinin derslerinde edebi ürün kullanımıyla ilgili karşılaştığı zorluklara genel olarak bakıldığında, zaman darlığı, kaynak yetersizliği ve sınav odaklı anlayıştan dolayı öğrencilerin yeterince ilgi göstermemesi görüşlerinin ön plana çıktığı görülmektedir. Burada özellikle öğretmenlerin dikkat çektikleri nokta sorunun öğretmen ya da öğrenciden ziyade sisteme ilişkin farklı noktalardan kaynaklandığı gerçeğidir. Diğer bir husus, edebi ürünlere ilişkin program ve kitaplardaki kaynakların yetersiz kalması öğretmenleri farklı alternatiflere yöneltmekte ve bu durum da ister istemez eğitim öğretim sürecini olumsuz etkilemektedir.

Sosyal bilgiler öğretmenleri derslerinde edebi ürün kullanırken karşılaştıkları zorluklar ile ilgili olarak K32: "Öğrencilerin hazırcı bir zihniyet ile internet üzerinden kısaltılmış özetlerle bu eserlere ulaşmaları büyük sıkıntı oluşturmaktadır”, K20: "En önemli sorun zaman yetersizliği. Bu ürünler üzerinden işlenen konular daha fazla zaman alıyor”, K23: "Sinıflarımızın bu etkinliklerimizi sergilemede mekan olarak yetersizliği ve kaynak noktasında yaşadığımız sıkıntılar ifade edilebilir” şeklinde görüşlerini belirtmişılerdir.

\section{-Öğretmenlerin derslerde edebi ürünlerin daha etkili kullanılabilmesi için yaptıkları öneriler:}

Sosyal bilgiler öğretmenlerinin derslerde edebi ürünlerin daha etkili kullanılabilmesi için yaptıkları önerilere ilişkin görüşlere ait cevaplar Tablo 10'da verilmiştir.

Tablo 10. Sosyal bilgiler öğretmenlerinin derslerinde edebi ürünlerin daha etkili kullanılabilmesi için yaptıkları öneriler

\begin{tabular}{lcc}
\hline \multicolumn{1}{c}{ Görüşler } & f & \% \\
\hline Dersin içeriğindeki edebi metinlerin sayısı arttırılması & 10 & 33.33 \\
\hline Öğrenci seviyesine uygun ve ilgi çekici edebi metinlerin tercih edilmesi & 9 & 30 \\
\hline
\end{tabular}




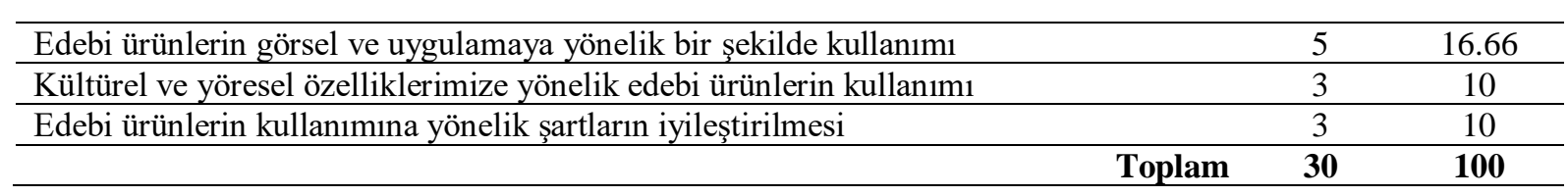

Tablo 10'da görüldüğü üzere sosyal bilgiler öğretmenlerinin derslerinde edebi ürünlerin daha etkili kullanılabilmesi için yaptıkları önerilere ilişkin görüşlerine ver verilmiştir. Tablo incelendiğinde en fazla tercih edilen görüşler sırasıyla; dersin içeriğindeki edebi metinlerin sayısı arttırılması (10), öğrenci seviyesine uygun ve ilgi çekici edebi metinlerin tercih edilmesi (9), edebi ürünlerin görsel ve uygulamaya yönelik bir şekilde kullanımı (5), kültürel ve yöresel özelliklerimize yönelik edebi ürünlerin kullanımı (3) edebi ürünlerin kullanımına yönelik şartların iyileştirilmesi (3) şeklindedir. Sosyal bilgiler öğretmenlerinin derslerinde edebi ürünlerin nasıl daha nitelikli kullanılabileceğine ilişkin görüşlerine genel olarak bakıldığında, olumlu ve yapıcı nitelikte farklı alternatif önerilerin olduğu görülmektedir. Özellikle derse ilişkin kaynak noktasında yetersizliği giderici önlemlerin alınması üzerinde durulurken aynı zamanda öğrenciyi derse çekecek uygun nitelikte edebi metin tercih edilmesi de ifade edilmiştir. Ayrıca edebi ürünlerin, öğrencileri dersin sıkıcı ortamından kurtarmak amacıyla uygulamaya dönük bir şekilde kullanılmasının da önemli olduğu belirtilmiştir. İfade edilen diğer bir husus ta edebi ürünlerin kendi kültürümüzü yansıtan ve vatan ve millet sevgisini aşllayan özelliklere sahip olması gerektiğidir.

Sosyal bilgiler öğretmenleri derslerinde edebi ürünlerin nasıl daha nitelikli kullanılabileceğine ilişkin olarak K27: "Edebi ürünlerin konularla bağlantı kurulacak şekilde güncel ve ilgi çekici olanlardan tercih edilmesinin daha uygun olacağını düşünüyorum", K16: "Ders kitaplarındaki konu içeriği dikkate alınarak daha fazla edebi metinlere ver verilebilir ve bu ürünler etkinliklerle sergilenebilir", K13: "Ders süresi ve ögretim programı, edebi ürünleri rahat bir şekilde kullanmaya uygun hale getirecek şekilde revize edilebilir" biçiminde düşüncelerini belirtmiş̧lerdir.

\section{Tartışma, Sonuç ve Öneriler}

Sosyal bilgiler dersinin çok disiplinli bir yapı arzetmesi ve konu alanı itibariyle geniş bir içeriğe sahip olması, farklı alanlara ilişskin unsur ve kaynaklardan yararlanma ihtiyacını da ortaya çıkarmıştır. Bu anlamda birbiri ile yakın ilişki içerisinde olduğu düşünülen ve birçok araştırma tarafindan da ortaya koyulan sosyal bilgileredebiyat birlikteliği bu duruma örnek olarak gösterilebilir. Sosyal bilgiler dersinin programında ifade edilen amaç ve hedeflerine ulaşmasında, edebiyat alanında ortaya konulmuş edebi ürünlerin birçok açıdan katkı sağlayacağı düşünülmektedir. Edebi ürünlerin özellikle sosyal bilgiler dersi dahilinde öğrencilere kazandırılması gereken bilgi, beceri, değer ve tutum noktasında kolaylaştırıcı bir etkide bulunduğu ve dersi zenginleştirici ve çekici hale getirdiği de ifade edilmektedir. Bu doğrultuda son hazırlanan 2018 sosyal bilgiler öğretim programında konuların işlenişinde edebi ürünlere yer verilmesi gerektiği belirtilmiş ve bunların bir kaynak olarak kullanımı da önerilmiştir. Sosyal bilgiler öğretmenlerinin derslerinde "edebi ürün" kullanma durumlarını ortaya koyarak değerlendirilmesini amaçlayan bu çalışmaya Bartın ilinde görev yapan toplam 32 sosyal bilgiler öğretmeni katılmıştır. Katılımcılar altı alt probleme ilişkin oluşturulan yarı yapılandırılmış soruları cevaplandırarak görüşlerini ifade etmişlerdir. Bu doğrultuda çalışmaya ilişkin aşağıdaki sonuçlara ulaşılmıştır:

Sosyal bilgiler öğretmenlerinin günlük hayatta takip etmekten hoşlandığı edebi ürünlere ilişkin çoğunlukla roman, hikaye, şiir, tiyatro ve şarkı/türkü’nün ön plana çıktığı görülmektedir. Bu durum bu edebi türlerin toplumda popüler olması, yaygın etki anlamında birçok insana hitap etmesi ve ulaşılabilirlik anlamında zenginlik arzetmesi şeklinde açıklanabilir. Yeşilbursa ve Sabancı'nın (2015) çalışmalarında sosyal bilgiler öğretmen adaylarının sosyal bilgiler öğretiminde kullanılabilecek edebi ürün tercihlerinde en fazla roman, hikaye ve şiirin olması da bu sonuçla örtüşmektedir. Buradan hareketle öğretmenlerin edebi ürün tercihlerinde çeşitlilik arzeden yaygın türleri ön plana çıkarmalarının öğrenci açısından bir zenginlik oluşturabileceği ve özellikle derslere olumlu bir şekilde yansıyacağı düşünülebilir.

Sosyal bilgiler öğretmenlerinin edebi ürünlerin sosyal bilgiler öğretim programı ve ders kitaplarındaki yeterliliğine ilişkin, çoğunlukla yeterli olmadığı görüşünün ortaya çıktığı görülmektedir. Bir kısım öğretmende yeterli ancak ders süresinin ve ilgili örneklerin yetersiz olduğu görüşünü beyan etmişlerdir. Bu durum öğretmenlerin edebi ürünleri derslerinde bir araç olarak kullanmayı önemsedikleri ve kullanım noktasında da olaya eleştirel bir tarzda baktıkları şeklinde değerlendirilebilir. Sömen ve Göksu'nun (2017) çalışmasında sosyal bilgiler öğretmenleri çoğunlukla, edebi ürünlerin öğrenci düzeyine uygun olmamasından ve ders saatinin 
yetersizliğinden bahsetmişlerdir. Aynı çalışmada sorunlara yönelik önerilerde de öğrenci düzeyine indirgenmesini ifade etmişlerdir. Buradan yola çıkarak sosyal bilgiler öğretim programı ve ders kitaplarındaki edebi ürün yeterliliğine ilişkin öğretmenlerin genel manada ortak düzeyde bir farkındalığa sahip oldukları ifade edilebilir.

Sosyal bilgiler öğretmenlerinin derslerinde edebi ürünleri kullanma gerekçelerine ilişkin görüşlerinde ön plana çıkan hususlar, tarih konularının anlaşılmasını kolaylaştırması ve derse olan ilgi ve merakı arttırmasıdır. $\mathrm{Bu}$ noktada edebi ürünlerin, öğrenciyi derse yakınlaştırması, ilgi uyandırması ve öğretiminde güçlük çekilen tarihi konulara yardımcı olması, özellikle derse sunduğu katkı açısından büyük önem taşımaktadır. Yeşilbursa ve Sabancı'nın (2015) çalışmalarında belirttiği üzere, sosyal bilgiler öğretmen adaylarının edebi ürünleri sosyal bilgiler disiplinleri içerisinde en fazla tarih ile ilişkilendirmesi ve edebi ürünlerin derse olan dikkati ve ilgiyi arttırdığını belirtmesi de bu düşünceyi doğrular niteliktedir. Aynı şekilde İbret vd.'nin (2017) çalışmasında da, sosyal bilgiler öğretmenleri büyük oranda edebi ürünleri tarihi konuları aktarmada bir araç olarak gördüklerini ifade etmişlerdir. $\mathrm{Bu}$ durumun bilhassa sosyal bilgilerde öğretiminde güçlük çekilen ve soyut olarak ifade edebileceğimiz konuların anlatımında, edebi ürün kullanımının öğretmene bir kolaylık sağlayacağı düşünülebilir.

Sosyal bilgiler öğretmenleri derslerinde kullandıkları edebi ürünlere ilişkin çoğunlukla roman, hikaye, tiyatro, şiir ve özlü sözler türlerini tercih ettiklerini ifade etmektedirler. Bu sonuç öğretmenlerin günlük hayatta takip etmekten hoşlandığı edebi ürün tercihleriyle büyük oranda benzerlik göstermektedir. Bu durum bir anlamda öğretmenlerin kişisel edebi ürün tercihlerinin derste kullanıma yönelik tercihlerini de etkilediği şeklinde yorumlanabilir. Beldağ ve Aktaş’ın (2016) araştırmalarında sosyal bilgiler öğretmenleri derslerinde çoğunlukla hikaye, destan, roman ve şiiri edebi eser olarak kullandıklarını ifade etmişlerdir. İbret vd.'nin (2017) yaptığı çalışmada da özellikle hikaye ve roman, sosyal bilgiler dersinde değerler öğretiminde kullanılan edebi ürünler arasında en fazla tercih edilenler arasındadır. Bir başka çalışma olan Sömen ve Göksu'da (2017) ise sosyal bilgiler öğretmenleri tarih konularının işlenişi esnasında en çok kullandıkları edebi ürün türleri arasında hikaye ve atasözünü göstermişlerdir. Ünlü’nün (2016) çalışmasında da benzer şekilde sosyal bilgiler öğretmenleri derslerinde en fazla kullandıkları edebi ürünler arasında hikaye, roman ve şiiri ifade etmektedirler. Buradan hareketle edebiyat alanında yaygın olan ve çok sayıda eser verilen bu edebi türlerin öğretmenler tarafından derste kullanımının, öğrencilerin bu türlere ve derse karşı olan ilgisini arttırabileceği şeklinde bir değerlendirme yapilabilir.

Sosyal bilgiler öğretmenlerinin derslerinde edebi ürün kullanımıyla ilgili karşılaştığı zorluklara ilişkin çoğunlukla programı yetiştirme ve zaman kaygısı, kaynak yetersizliği ve sınav odaklı sistemden dolayı öğrencilerin soğuk bakması görüşleri belirtilmiştir. Burada önemle üzerinde durulan husus zaman, kaynak ve sınav konuları olmuştur. Bu durumun sistemin geneline ilişkin dış faktörlerden kaynaklanan bir sorun olduğu ve ders sürecinde edebi ürün kullanımına olumsuz bir etkide bulunabileceği şeklinde değerlendirilebilir. Sömen ve Göksu'nun (2017) çalışmalarında konuya ilişkin, öğretmenler daha çok ders saatinin yetersizliğini sorun olarak gördüklerini ifade ederken Ünlü'nün (2016) çalışmasında da edebi metinlere erişim zorluğu büyük bir sorun olarak öğretmenler tarafindan dile getirilmiştir.

Sosyal bilgiler öğretmenlerinin derslerinde edebi ürünlerin daha etkili kullanılabilmesi için yaptıkları önerilere ilişkin görüşlerinde büyük oranda ders içeriğinde konulara paralel olarak edebi metinlerin sayısının arttırılabileceğini ve öğrenci seviyesine uygun ve ilgi çekici edebi metinlerin tercih edilmesi gerektiğini belirtmişlerdir. Burada öğretmenlerin genel öneri olarak sundukları bu konular, sosyal bilgiler dersinde program ve kitap noktasında yapılacak yeni düzenlemelerde edebi ürün konusu üzerinde hassasiyetle durulması gerektiği açısından önemlidir. Bu noktada öğretim programı ve kitap yazarı alan uzmanlarının, uygulayıcı konumundaki öğretmenlerin önerilerini dikkate almaları, eğitim-öğretim sürecinde birliğin sağlanması ve dersin verimliliğinin artmasında büyük önem taşımaktadır.

Araştırma sonuçlarına dayalı olarak şu önerilerde bulunulabilir:

- Sosyal bilgiler ögretim programında ve kitaplarda edebi ürünlerin etkili ve amacına uygun bir şekilde nasıl kullanılması gerektiğine yönelik açıklamalar yapılmalıdır.

- Sosyal bilgiler ders kitaplarında edebi ürünlerin türleri ve sayıları artırılmalıdır.

- Ö̆grenci seviyesine uygun, ilgi çekici ve işlevsel metinler tercih edilmelidir.

- $\quad$ Ögretmenlere yönelik sosyal bilgiler öğretiminde kullanilabilecek edebi tür örneklerini içeren kaynak kitaplar hazırlanabilir. 
- Sosyal bilgilerde edebi ürün kullanımına yönelik öğrenci görüşlerini esas alan farklı akademik çalışmalar yapılabilir.

\section{Teşekkür ve Bilgilendirme}

Bu araştırmanın bir bölümü, Muğla Sitkı Koçman Üniversitesi’nce 2016 yılında düzenlenen 15. Uluslararası Sınıf Öğretmenliği Eğitimi Sempozyumu'nda aynı adla sunulmuştur. 


\section{References}

Akkuş, Z. (2006). Sosyal Bilgiler Öğretiminde Destanlarin Kullanimi [The Use Of Epics In The Teaching Of Social Science.] Atatürk University Kazım Karabekir Faculty of Education Journal Dergisi (KKEFD), 14, 31-48.

Akyol, Y. (2011). 7. Sinıf Sosyal Bilgiler Dersi Türk Tarihinde Yolculuk Ünitesindeki Kazanımlar ve Gagne’nin Ögrenme Ürünleri [Gains in the unit the journey through the turkish history in 7th grade social studies course and Gagne's learning outcomes.] Unpublished master's thesis. Celal Bayar University, Institute of Social Sciences, Manisa.

Altun, A. and Ata, B. (2008). Türkiye'de sosyal bilgiler eğitim anabilim dalındaki akademisyenlerin ve öğretmen adaylarının başvuru kitapları üzerine düşünceleri. [The Opinions of Academicians and Prospective Teachers on Reference Books at the Departments of Social Studies Teachers Education in Turkey.] Kafkas Üniversitesi Sosyal Bilimler Enstitüsü Dergisi, 2, 27-45.

Altunay-Şam, E. (2011). "Şu Çılgın Türkler” romanının kuruluş savaşı bilgisini öğrenmeye etkisi. [The Effect Of "Şu Çilgin Türkler" On Learning The "War Of Independence Information"]. NWSA E-Journal of New World Sciences Academy Education Sciences, 6 (4), 2555-2568.

Altunay-Şam, E. and İskender-Kılıç, P. (2011). Tarihsel romanın eğitimsel işlevi üzerine bir çalışma: "diriliş" romanı örneği. [The Study on Educational Function of Historical Novel: In Case of Diriliş Novel] Ondokuz Mayls University Faculty of Education Journal, 30 (1), 123-144.

Arslan, E. (2014). Ortaokul 7. sınıf sosyal bilgiler dersinde hikâye anlatım yönteminin akademik başarıya etkisi. [The effect of storytelling method on academic success in secondary school $7^{\text {th }}$ grade social studies course]. Unpublished master's thesis. Gaziantep University, Institute of Social Studies, Gaziantep.

Bacak, S. (2008). Illköğretim 5. sınıf sosyal bilgiler dersinde öykü tabanlı öğrenme yaklaşımının öğrenenlerin akademik başarı ve yaratıcılıklarına etkisi. [Effect of story-based learning approach on academic success and creativity of learners in primary school $5^{\text {th }}$ grade social studies course]. Unpublished master's thesis. Celal Bayar University, Institute of Social Sciences, Manisa.

Beldağ, A. and Aktaş, E. (2016). Sosyal bilgiler öğretiminde edebî eser kullanımına ilişkin öğretmen ve öğretmen adaylarının görüşleri. [Teachers' and teacher candidates' opinions on use of literary works in social studies teaching.] Erzincan University Faculty of Education Journal, 18 (2), 953-981.

Bölücek, B. (2008). Sosyal bilgiler ögretiminde türkülerden yararlanmanın ögrrencilerin akademik başarısına etkisi.[The Effect of Folk Songs on the Academic Success in the Teaching of Social Studies]. Unpublished master's thesis. Gazi University, Institute of Education Sciences, Ankara.

Büyüköztürk, Ş., Kılıç-Çakmak, E., Akgün, Ö. E. Karadeniz, Ş. and Demirel, F. (2008). Bilimsel araştırma yöntemleri. [Scientific Research Methods]. Ankara: Pegem A Yayıncılık.

Çencen, N. (2017). Ortaokul öğrencilerinin Türkiye Cumhuriyeti İnkılâp Tarihi ve Atatürkçülük dersinde tarihsel mektupların kullanımına ilişkin görüşleri: Ankara ili ODTÜ geliştirme vakfı ortaokulu örneği. [Secondary School Students' Views on the Use of Historical Letters in Turkish Republic History of Revolution and Kemalism Course: Ankara, ODTÜ Geliştirme Vakfı Middle School Example] Education and Science, 42 (192), 193-210.

Çencen, N. and Akça-Berk, N. (2014). Ortaöğretim T.C. İnkılâp Tarihi ve Atatürkçülük Dersinde "şiir kullanımına" ilişkin öğretmen görüşleri. [Perspectives of the Teachers Related to the "Use of Poem" in Secondary Education Turkish Republic Revolution History and Kemalism Course]. Turkish History Education Journal, 3 (1), 1-23.

Çengelci, T. (2013). Sosyal bilgiler dersinde yararlanılan toplumsal ve kültürel kaynakların belirlenmesi. [Determining social and cultural resources being used in the social studies course]. Electronic Journal of Social Studies, 12 (43), 219-236. 
Çifçi, T. (2011). Sosyal bilgiler öğretiminde tarihi romanların kullanımının ögrencilerin akademik başarısı üzerine etkisi. [The effect of using historical novels on students' academic achievement in teaching social studies]. Unpublished master's thesis. Gazi Univerity, Institute of Education Sciences, Ankara.

Demir, S. B. (2011). Sosyal bilgiler ögretim programına göre tasarlanmış hikâyelerin etkililiği. [Effectiveness of stories designed based on social studies curriculum]. Unpublished Doctorate Thesi. Marmara University, Institute of Education Sciences, İstanbul.

Doğanay, A. (2005). Social Studies Teaching. In C. Öztürk and D. Dilek (Ed.), Hayat Bilgisi ve Sosyal Bilgiler Ögretimi [Life Sciences and Social Studies Teaching] (pp. 17-52). Ankara: Pegem A Publishing.

Dönmez, C. and Altıkulaç, A. (2014). Sosyal bilgiler öğretmen adaylarının Ortaokul T.C. İnkılâp Tarihi ve Atatürkçülük dersi konularının öğretiminde tarihsel kaynakların kullanımına yönelik görüşleri. [Social studies teacher candidates' opinions regarding using historical sources in teaching of T.R. history of the revolution and Kemalism course in secondary school] Kastamonu Education Journal, 22 (3), 923-942.

Er, H. (2008). İlköğretim öğrencilerine sosyal bilgiler eğitiminde biyografi öğretimi çerçevesinde Atatürk'ün hayatı nasıl anlatılmalıdır? [How should Atatürk's life be taught to primary school students in social studies education within the scope of biography teaching]. In, International Symposium on Social Studies Teaching Proceedings Book (pp. 388-394). Çanakkale: Çanakkale Onsekiz Mart University Print.

Er, H. (2010). Sosyal bilgiler eğitimi kapsamında ilköğretim öğrencilerinin "biyografi" kullanımına ilişkin görüsleri. [Opinions of primary school students on use of "biography" within the scope of social studies education]. Unpublished doctorate thesis. Gazi University, Institute of Education Sciences, Ankara.

Er, H. and Şahin, M. (2012). Sosyal bilgiler dersinde "biyografi” kullanımına ilişkin öğrenci görüşleri. [Student opinions on the use of "biography" in social studies course]. Journal of Turkish Education Sciences, 10 (1), 75-96.

Erdem, R. (2010). Sosyal bilgiler ögretiminde biyografi kullanımı. [Use of biography in social studies teaching]. Unpublished master's thesis. Niğde University, Institute of Social Studies, Niğde.

Erdoğan, N. (2007). İlköğretim sosyal bilgiler dersi tarih konularının öğretiminde resimlendirilmiş öykülerin tarihsel düşünme becerilerinin gelişimine etkisi. [The effect of illustrated stories on the development of historical thinking skills in primary education social studies course history subjects]. Unpublished master's thesis. Marmara University, Institute of Education Sciences, İstanbul.

Field, H. (2009). Sosyal bilgilerin tanımı, amacı, önemi ve Türkiye'deki yeri. [The definition, aim, importance of social studies and its place in Turkey]. In R. Turan, A. M. Sünbül and H. Akdağ. (Eds.), New Approaches in Social Studies Teaching I (ss. 1-24). Ankara: Pegem A Publishing.

Fredericks, A. D. (2007). Much more social studies through children's literature: A collaborative approach. London: Teacher Ideas Press.

Gevenç, S. (2014). Sosyal bilgiler ögretiminde fikraların kullanımı. [The use of jokes in social studies teaching] Unpublished master's thesis. Niğde University, Institute of Education Sciences, Niğde.

İbret, B. Ü., Karasu-Avcı, E., Karabıyık, Ş., Güleş, M. and Demirci, M. (2017). Sosyal bilgiler öğretmenlerinin görüşlerine göre değerlerin öğretiminde edebi ürünlerin kullanımı. [The use of literature products in teaching the values by social studies teachers] International Journal of Turkish Education Sciences, 5 (9), 104-124.

Kaya, E. and Ekiçi, M. (2015). Sosyal bilgiler öğretiminde gezi yazılarından yararlanma: Gülten Dayığlu'nun gezi yazıları örneği, [Usage of travel writings in social studies teaching: Gülten Dayioğlu case travel writings]. Turkish Journal of Social Researches 19 (1), 87-114.

Kaymakc1, S. (2008). İlköğretim öğrencilerinin Atatürk'ün Gençliğe Hitabesi'ni anlama ve tarihi olaylarla ilişkilendirme düzeyine bir bakış. [An overview of primary school students' level of understanding Atatürk's Address to the Turkish Youth and associating it with historical events]. In, International Symposium on Social Studies Teaching Proceedings Book (pp. 388-394). Çanakkale: Çanakkale Onsekiz Mart University Print. 
Kaymakcı, S. (2010). Sosyal bilgiler öğretiminde çalışma yaprakları kullanımının öğrencilerin akademik başarılarına ve derse karşı tutumlarına etkisi. [Effect of worksheet usage in social studies teaching on students' academic success and attitude towards the course]. Unpublished doctorate thesis. Gazi University, Institute of Education Sciences, Ankara.

Kaymakcı, S. (2013). Sosyal bilgiler ders kitaplarında sözlü ve yazılı edebî türlerin kullanım durumu. [The usage situation of oral and written literary works in social studies textbooks]. Dicle University Ziya Gökalp Faculty of Education Journal, 20, 230-255.

Kaymakcı, S. (24-26 May 2012). Ilköğretim 4. ve 5. sınıf sosyal bilgiler ders kitaplarında edebî ürünlerin kullanımina bir bakıs. [An overview of use of literary works in primary education $4^{\text {th }}$ and $5^{\text {th }}$ grade social studies textbooks]. Presented in $11^{\text {th }}$ International Symposium on National Classroom Teaching, Rize.

Kaymakc1, S. and Er, H. (2009). Sosyal bilgilerde biyografi kullanımı. [Use of biography in social studies]. In M. Safran (Ed.), Social Studies Teaching (s. 413-431). Ankara: Pegem A Publishing.

Kaymakcı, S. and Er, H. (2013). Sosyal bilgiler öğretim programı ve ders kitaplarında biyografinin kullanımı. [The Usage of Biography in Social Studies Curricula and Textbooks]. Mehmet Akif Ersoy University Faculty of Education Journal 13 (25), 198-224.

Keskin, S. (2008). Romanlarla tarih eğitimi ve ögretimi. [History teaching with novels] Unpublished master's thesis. Selçuk University, Institute of Social Sciences, Konya.

Krey, D. (1998). Children's literature in the social studies: Teaching to the standards. NCSS Bulletin 95. Washington, DC: National Council for the Social Studies.

Kuran, Ş.B. and Ersözlü, Z. N. (2009). Sınıf öğretmenlerinin çocuk edebiyatına ilişkin görüşleri. [Opinions of classroom teachers on children's literature]. Yüzüncü Yıl University Faculty of Education Journal, 6 (1), 117.

Kuş, E. (2012). Nicel-nitel araştırma teknikleri. [Quantitative-qualitative research methods]. Ankara: Anı Publishing.

Küçükoğlu, H. (2010). Importance of literature in children's development with some suggested activities. In, D. Şahhüseyinoğlu \& D. Ilisko (Eds.), How Do Children Learn Best? (pp.144-157), Ankara: Researcher Children Center.

McGowan, T. ve Guzzetti B. (1991). Edebiyat temelli sosyal bilgiler öğretimi. [Literature based social studies teaching] A. Doğanay (Transl.). Retrieved from http://turkoloji.cu.edu.tr/GENEL/doganay_01.pdf on 16/01 2018.

MEB. (2005a). İlköğretim sosyal bilgiler dersi 4-5. sinıflar ögretim programı (taslak basım). [Primary education social studies course 4-5th grades curriculum and guidelines (draft issue)] Ankara: MEB.

MEB. (2005b). Illköğretim sosyal bilgiler dersi 6-7. sinıflar öğretim programı ve kılavuzu (taslak basım). [Primary education social studies course 6-7 $7^{\text {th }}$ grades curriculum and guidelines (draft issue)] Ankara: MEB.

MEB. (2018). Sosyal bilgiler dersi ögretim programı (ilkokul ve ortaokul 4, 5, 6 ve 7. sinıflar). [Social studies course curriculum (primary and secondary school $4^{\text {th }}, 5^{\text {th }}, 6^{\text {th }}$ and $7^{\text {th }}$ grades)] Ankara: MEB.

Mertol, H. (2008). İlköğretim sosyal bilgiler dersinde çocuk edebiyatı ürünlerinin kullanımına yönelik öğretmen görüşleri ve uygulamaları. [Teacher opinions and applications regarding the use of children's literature works in primary teaching social studies course]. In, International Social Studies Teaching Symposium Proceedings Books (pp. 265-269). Çanakkale: Çanakkale Onsekiz Mart University Print.

Meydan A. ve Akdağ, H. (2014). Sosyal bilgiler dersinde öğretim teknolojileri ve materyal tasarımı. [Teaching technologies and material design in social studies course] In B. Tay and A. Öcal (Eds.), Social studies teaching with special teaching methods (pp. 153-192). Ankara: Pegem A Publishing.

Miles, M. B.ve Huberman, A. M. (1994). Qualitative data analysis: An expanded sourcebook. Thousand Oaks, California: SAGE Publications, Inc. 
Neitz, L. J. (2002). Impact of children's literature as an ancillary component to the social studies. Unpublished master's thesis. Retrieved from https://files.eric.ed.gov/fulltext/ED469403.pdf on 07/05/2018.

Oruç, Ş. (2009). Sosyal bilgiler 6. sınıf ders kitaplarında edebi ürünler. [Literary works in social studies $6^{\text {th }}$ grade textbooks]. Turkish Journal of Social Researches, 13 (2), 9-24.

Oruç, Ş. and Erdem, R. (2010). Sosyal bilgiler öğretiminde biyografi kullanımının öğrencilerin sosyal bilgiler dersine ilişkin tutumlarına etkisi. [Effect of biography usage on attitude of students towards social studies course]. Selçuk University Ahmet Keleşoğlu Education Faculty Journal, 30, 215-229.

Öztürk, A. (2002). Tarih ögretiminde tarihi romanlartn kullantlmast. [Use of historical novels in history teaching]. Unpublished master's thesis. Gazi University, Institute of Education Sciences, Ankara.

Öztürk, C. ve Otluoğlu, R. (2002). Sosyal bilgiler öğretiminde yazılı edebiyat ürünlerini ders aracı olarak kullanmanın duyuşsal davranış özelliklerini kazanmaya etkisi. [The effect of using literary materials to acquire affective behaviors in social studies teaching]. Marmara University Atatürk Education Faculty Journal of Education Sciences, 15, 173-182.

Patton, M. Q. (2014). Nitel araştırma ve değerlendirme yöntemleri. [Qualitative research and evaluation methods]. M. Bütün, S. Beşir Demir (Transl. Ed.). Ankara: Pegem A Publishing.

Sever, S. (1998). Demokratik kültür edinimi sürecinde dil ve edebiyat öğretimi. [Language and literature teaching in democratic culture acquisition process]. Journal of Education for Life, 56, 4-5.

Sömen and Göksu (2017). Sosyal bilgiler öğretmenlerinin derslerinde sözlü ve yazılı edebi ürünleri kullanmaları durumu. [Social studies teachers' oral and written literary works usage situation in their courses]. Turkish Studies, Volume 12/18, p. 561-576.

Şimşek, A. (2000). Illköğretim sosyal bilgiler dersinin ögretiminde hikaye anlatım yönteminin (storytelling) kullanımı. [Use of storytelling method in primary education social studies teaching]. Unpublished master's thesis. Gazi University, Institute of Social Sciences, Ankara.

Şimşek, A. (2006a). Bir öğretim materyali olarak tarihsel romana yönelik öğrenci ve öğretmen görüşleri. [Students' and history teachers' opinions towards historical novel as a teaching material]. TOJET (The Turkish Online Journal of Educational Technology), 5 (4), 73-81.

Şimşek, A. (2006b). İlköğretim sosyal bilgiler dersinde tarihsel hikâyeye yönelik öğrenci görüşleri. [The Opinions of Students About Historical Story in Social Studies in Elementary Schools]. Gazi University Gazi Education Journal, 26 (11), 187-202.

Tekgöz, (2005). Illköğretim 7. sınıf sosyal bilgiler dersinde edebiyat temelli öğretimin öğrenci başarısına etkisi. [Effect of literature based teaching on student success in primary education $7^{\text {th }}$ grade social studies course]. Unpublished master's thesis. Çukurova University, Institute of Social Sciences, Adana.

Tokcan, H. (2016). Sosyal bilgiler ve edebiyat. [Social studies and literature]. In H. Tokcan (Ed.), Oral and Written Literature Reviews in Social Studies (pp.1-24). Ankara: PegemA.

Tokdemir, M. A. (2016). Osmanlı Devleti’nin kuruluşunun öğretilmesinde tarihsel roman kullanımı: Devlet ana romanını okumak. [Teaching Ottoman Empire's Foundation Via Using Historical Novels: Reading The Novel Of Devlet Ana]. Kastamonu Education Journal, 24 (3), 1469-1486.

Top, M. (2009). İlköğretim 8. sınıf T.C. Inkılâp Tarihi ve Atatürkçülük dersinin ögrretiminde edebî ürünlerin kullanımının ögrenciye başarıs ve tutumuna etkisi.[Effect of the use of literary works in 8th grade Revolution and Kemalism courses on students' attitude and success]. Unpublished master's thesis. Marmara University, Institute of Education Sciences, İstanbul.

Topçu, E. and Kaymakcı, S. (2018). Sosyal bilgiler öğretiminde menkıbelerin kullanılma durumuna ilişkin öğretmen görüşleri. [Teachers' Perceptions About the Usage of Legends in Social Studies Education]. Erzincan University Faculty of Education Journal, 20 (1), 281-305.

Ünlü, İ. (2016). Sosyal bilgiler öğretmenlerinin ders materyali olarak edebi ürün kullanımına yönelik görüşleri. [The viewpoints of social sciences teachers on the use of literary genres as class materials]. International Journal Of Eurasia Social Sciences, 7 (22), 120-136. 
Ünlü, İ. and Kaşkaya, A. (2018). Sosyal bilgiler dersi öğretmen adaylarının, ek kaynak ve materyal olarak tarihi roman kullanma yeterliklerinin ders planları üzerinden incelenmesi. [Examining the social studies teacher candidates' efficacy on using historical novels as additional sources and materials]. Turkish History Education Journal, 7 (1), 69-91.

Yeşilbursa, C. C., Sabancı, O. and Hamarat, E. (2013). Sosyal bilgiler ders kitaplarında edebi ürünlerin kullanımı. [Use of literary works in social studies textbooks] In B. Akbaba (Ed.), Social Studies Subject Area Textbook Research Guide (pp. 145-206). Ankara: Pegem A Publishing.

Yeşilbursa, C.C. and Sabancı, O. (2015). Sosyal bilgiler öğretmen adaylarının sosyal bilgiler öğretiminde edebi ürünlerin kullanımına yönelik görüşleri. [Pre-Service Social Studies Teachers' Views on Using Of Literary Works in Social Studies Teaching]. Mehmet Akif Ersoy University Faculty of Education Journal, 15 (36), 1933.

Yıldırım, A. and Şimşek, H. (2011). Sosyal bilimlerde nitel araştırma yöntemleri. [Qualitative research methods in social studies]. Ankara: Seçkin Publishing.

Yıldırım, M. (2017). Sosyal bilgiler ögretmenlerinin derslerinde edebi ürün kullanma durumları (Erzurum örneği). [Social studies' teachers literary work usage situation in their courses (Case of Erzurum)]. Unpublished master's thesis. Atatürk University, Institute of Education Sciences, Erzurum.

Yiğit, E. Ö. (2007). Öyküleştirme yönteminin 6. sinıf sosyal bilgiler programı ülkemizin kaynakları ünitesindeki ögrenci başarisl üzerine etkisi.[Effect of storyline method on student success in $6^{\text {th }}$ grade social studies program sources of our country unit]. Unpublished master's thesis. Abant İzzet Baysal University, Institute of Social Sciences, Bolu. 